"By Pernambuco being so near": annexation, governments and overseas markets in the Captaincy of Paraiba (1791-1799)

\section{"Por ser Pernambuco tão chegado": anexação, governos e mercados ultramarinos na Capitania da Paraíba (1791-1799)}

\author{
José Inaldo Chaves Júnior ${ }^{1}$ \\ Doutorando em História pela \\ Universidade Federal Fluminense \\ (UFF - Niterói/Rio de Janeiro), \\ professor assistente da Universidade \\ Federal do Sul e Sudeste do Pará \\ (UNIFESSPA - Marabá/Pará) e \\ bolsista do Conselho Nacional \\ de Desenvolvimento Científico e \\ Tecnológico (CNPq). \\ e-mail: inaldochavesjr@gmail.com
}

\begin{abstract}
Resumo
Em 1794, em um dos últimos episódios daquele século no que diz respeito ao comércio intercolonial nas capitanias do Norte, uma ordem régia autorizou os tráficos mercantis entre zonas produtoras da Capitania da Paraiba e o porto do Recife, principal entreposto comercial da região. A autorização régia foi emitida nos estertores do chamado período de anexação (1756-99), quando a Paraíba estava subordinada ao governo de Pernambuco, e contrariava os planos do então governador da Paraiba, o capitão-mor Jerónimo de Mello e Castro, que desejava criar mecanismos políticos e econômicos que permitissem recobrar a autonomia da Capitania. Destarte, a relação entre o plano local, representado pelas interações entre produtores e negociantes nas capitanias do Norte, e o plano imperial, que expôs o interesse da Coroa portuguesa, em fim de século, em estimular o comércio intercolonial, será o objeto precípuo desse artigo.
\end{abstract}

\begin{abstract}
In 1794, in one of the last episodes of that century with regard to the intercolonial trade in North captaincies a royal order authorized the commercial trafficking between producing areas of the Captaincy of Paraiba and the port of Recife, the main commercial hub of the region. The royal authorization was issued in the throes of the so-called period of annexation (1756-99), when Paraiba was subordinated to the government of Pernambuco, and contradicted the plans of the then governor of Paraiba, the chief captain Jerónimo de Mello e Castro, who wished to create political and economic mechanisms that allow recovering the autonomy of the Captaincy. Thus, the relationship between the local sphere, represented by interactions between producers and dealers in North captaincies, and the imperial sphere, which exposed the interest of the Portuguese Crown at the end of the century, to promote intercolonial trade, will be the prime object of this article.
\end{abstract}

\section{Palavras-chave}

Império português, capitanias do Norte, comércio ultramarino, elites locais.

Keywords

Portuguese Empire, North captaincies, overseas trade, local elites.
Agradeço muitíssimo as críticas e sugestões de Maria Fernanda Bicalho (UFF), Carlos Gabriel Guimarães (UFF) e Adriana Romeiro (UFMG). A estes dedico o presente estudo. 
2 Junta de Comércio, ANTT, maço. 367, cx. 738.

3

Em 1756, por ordem régia, o governo da Paraíba foi suprimido e anexado ao de Pernambuco, sob a alegação da falta de meios em se manter um governo autônomo na Capitania. 0 estado de subordinação permaneceu até 1799 , sendo que $2 / 3$ desse período a Paraiba foi governada pelo capitão-mor Jerónimo de Mello e Castro (1764-1797). Para mais detalhes, cf. CHAVES JR., José Inaldo. As duras cadeias de hum governo subordinado: história, elites e governabilidade na Capitania da Paraiba (c.1755-c.1799). 2013. Dissertação (Mestrado em História), Universidade Federal Fluminense, Niterói, 2013; cf. também OLIVEIRA, Elza Regis de. A Paraiba na crise do século XVIII: subordinação e autonomia (17551799). $2^{a}$ ed. João Pessoa: Editora Universitária/ UFPB, 2007.

4 AHU - Paraiba, doc. 2240, grifos nossos.

5 Cf. VALADARES, Virginia Maria Trindade. $A$ sombra do poder: Martinho de Melo e Castro e a administração da Capitania de Minas Gerais (1770-1795). São Paulo: HUCITEC, 2006, p. 208-9.

6

Antes de assumir a secretaria, Luis Pinto de Souza Coutinho foi governador da Capitania do Mato Grosso.
Na política e no comércio, propõem-se aparências e ocultam-se as realidades [...]

(Trecho de carta da Junta de Comércio de Lisboa). ${ }^{2}$

\section{Introdução}

Na cidade da Paraíba, por volta de 1795 , já se passara mais de trinta anos desde que atracara no seu porto a nau trazendo o coronel Jerónimo José de Mello e Castro, que chegara aos trópicos orientais da América Portuguesa com a difícil missão de gerir um governo subordinado, política e administrativamente, a Pernambuco. Entretanto, o que talvez Jerónimo de Mello e Castro jamais imaginasse era o quão complicado seria manter os limites mínimos da governabilidade naqueles territórios quando os interesses de setores importantes das elites locais teimavam em implodir as fronteiras entre as duas capitanias. ${ }^{3}$

Em 29 de maio de 1795, uma sexta-feira que o tempo preservou vestígios, o capitão-mor Mello e Castro manifestou sua indignação diante de um dos temas mais tensionados e controversos nas capitanias do Norte nesse período: o comércio direto entre as zonas produtoras da Paraíba e o entreposto do Recife, que corria sem recolhimento de tributos na cidade da Paraíba. Na visão do governador, esses circuitos mercantis fraudavam a fazenda real, além do que endossavam a danosa subordinação. Todavia, não era a primeira missiva na qual ele revelara uma opinião contrária ao comércio exportador intermediado pelo porto do Recife; mais que isto, Jerónimo fez questão de anunciar suas ações para sustá-lo, interrompê-lo.

Poucos anos antes, em 15 de junho de 1791, Jerónimo anunciou ao secretário de Estado da Marinha e Ultramar, Martinho de Mello e Castro, a apreensão de um carregamento clandestino de açúcar nas ribeiras do Mamanguape, ao norte da cidade da Paraiba, que seguia em direção à praça do Recife. Nesta ocasião, foi possivel ter uma dimensão minúscula do comércio movimentado entre as duas capitanias e, por conseguinte, dos problemas que este acarretava, na interpretação do governador da Paraíba.

Este anno que não promettia produção vantajoza attenta a grande distruição [sic] que padecerão os Engenhos e Canaviais com o dilúvio de 1789, já dou carga a dois Navios [...] e esta prompta carga para outro, e para muitos haveria se as referidas 82 caixas [de açúcar] não fossem para Pernambuco e muitas sacas de algudão, couros, solas, e mais grande [sic] abundancias e effeitos, que sahem desta Capitania para aquela. ${ }^{4}$

Doravante, naquele outono de 1795, outros detalhes apontaram para a articulação do plano local da governabilidade com as estratégias da Coroa para o fortalecimento do comércio nas capitanias do Norte. Neste mesmo ano, precisamente em 24 de março, morrera o primo do capitão-mor da Paraíba e secretário de Estado, Martinho de Mello e Castro, um conhecido admirador das doutrinas mercantilistas. ${ }^{5}$ Em seu lugar, assumira Luis Pinto de Souza Coutinho a estratégica secretaria de Estado da Marinha e Ultramar. ${ }^{6}$ Coincidentemente ou não, a carta de Jerónimo José de Mello e Castro era, na verdade, uma resposta à Sua Majestade, a rainha d. Maria I, que lhe ordenara que fossem imediatamente levantadas quaisquer proibições de comércio entre a Paraiba e Pernambuco. Na verdade, o comércio inter e intracolonial esteve na pauta das preocupações do secretário Mello e Castro, que julgava serem excessivas e perniciosas as liberdades conferidas aos homens de negócio brasilicos, que já não mais se contentavam com o controle exercido sobre as rotas mercantis com a África, responsáveis pelo abastecimento escravo da América Portuguesa: 
7

AHU - Brasil, doc. 1976 (c.1777). Devo a Dra. Érika de Almeida Dias (UNL/CHAM) o acesso a esta importante fonte.

8

Idem. Novais chama a atenção para as instruções dadas pela autoridade metropolitana ao conde de Rezende (1790), que notava "o fato de que a navegação brasileira 'tem mudado de figura'. Antes, eram navios dos comerciantes das praças do Reino; agora os proprietários são negociantes da Bahia, Rio de Janeiro, Pernambuco, que navegam para a Mina, Angola, Benguela - o que dava lugar a intenso contrabando com os estrangeiros" (NOVAIS, Fernando Antônio. Portugal e Brasil na crise do Antigo Sistema Colonial (1777-1808). $8^{\text {a }}$ ed. São Paulo: HUCITEC, 1995, p.196-7).

9

DIAS, Érika Simone de Almeida Carlos. Alguns aspectos da administração do Brasil no século XVIII na perspectiva dos secretários da Marinha e Ultramar. In.: APOLINÁRIO, Juciene Ricarte (org.) Paisagens hibridas. Campina Grande: EDUEPB, 2011, p. 249-279.

10

Discutindo o chamado período da "viradeira", do reinado de d. Maria I e os desdobramentos da queda de Sebastião de Carvalho e Melo, Fernando Antônio Novais destacou: "[...] houve sim uma viragem significativa, mas no sentido de uma maior integração nas linhas do reformismo ilustrado. Foi, efetivamente, no periodo de D. Maria I e do Príncipe Regente Dom João que Portugal se abriu mais largamente aos influxos da Ilustração europeia" (NOVAIS, Fernando Antônio. Op. Cit., p. 224)

11

GONÇALVES, Regina Célia. Guerras e açúcares: política e economia na Capitania da Parayba 1585-1630. Bauru: EDUSC, 2007, sobretudo os capítulos 2 e 3 .

12

Entretanto, foi somente em 1772, com a criação da vila de Pombal, que os territórios "d'além da Serra da Copaoba" - sertões - ganharam representação concelhia. Antes disso, o espaço nessas áreas era organizado apenas em função das ribeiras, freguesias, capitanias-mores e julgados; uma situação jurisdicional anômala. Em seu total, ao longo da segunda metade de Setecentos, foram criadas as vilas de Monte-mor, o novo, São Miguel da Baía da Traição, Nossa Senhora do Pilar, Conde, Alhandra, Pombal, Vila Nova da Rainha (Campina Grande), Vila Real de São João (Cariri Velho) e Vila Nova de Souza. Para mais detalhes sobre as reformas territoriais na Paraíba do século 18, seus limites e inserção no reformismo ilustrado português, cf. o estudo de CARVALHO, Juliano Loureiro de. Formação territorial da Mata Paraibana, 1750-1808. Dissertação (Mestrado em Arquitetura e Urbanismo), Universidade Federal da Bahia, Salvador, 2008, p. 68.
[...] Porque depois que dos portos de Portugal passou para o Brasil todo o comércio da costa da África... [os americanos] já se não contentam com esta vantagem, mas querem, independentemente da mesma metrópole, ter no seu próprio continente e imediatamente dos portos da [Ásia]... ${ }^{7}$

0 referido secretário de estado acreditava que, diante do número de navios pertencentes às frotas brasileiras, notavelmente de Pernambuco, Bahia e Rio de Janeiro, a América Portuguesa poderia facilmente subsistir sem Portugal, uma vez que, em finais de Setecentos, até o algodão - uma das forças-motrizes da Revolução Industrial na Europa - já fazia parte de seus ganhos. ${ }^{8}$ Segundo Érika Dias, Martinho de Mello e Castro representou "o caráter dualista do Governo de D. Maria I", pois se "por um lado achava ser necessário reformar o país e suas colônias", do que se depreende sua íntima vinculação ao reformismo ilustrado capitaneado pelo marquês de Pombal, "[...] por outro achava que era preciso subjugar as liberdades que o Brasil foi adquirindo ao longo dos séculos por sua posição geográfica e pelas poten-

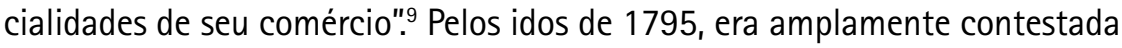
a perspectiva que enxergava na relação colônia-metrópole um antagonismo radical de interesses. Por dentro dos próprios quadros da administração portuguesa, outros entendimentos do chamado pacto colonial eram elaborados, assinalando o refinamento do reformismo ilustrado lusitano. ${ }^{10}$

Sem que possamos confirmar uma relação direta entre a morte do Secretário e a destacada decisão régia de permitir o comércio intracolonial nas capitanias de Pernambuco e Paraiba - reiteradamente proibido noutras conjunturas, como veremos -, o que nos parece evidente são os novos rumos da política econômica imperial a partir da década de 1790, quando Martinho de Mello e Castro já se encontrava adoentado. Uma decisão régia de 10 de julho de 1794 objetivava precisamente a liberação dos negócios entre o Recife e as regiões próximas do rio Mamanguape - segunda maior população e baia hidrográfica da Paraiba, cuja importância mostrava-se crescente desde o início de Setecentos.

A bacia do rio Paraiba constituiu-se na principal área de povoamento e proveito açucareiro da Capitania, embora, já na terceira década do mesmo século, outras zonas estivessem em processo de ocupação, especialmente ao norte da Paraiba. ${ }^{11}$ Somente a partir de meados de Seiscentos, o entorno do rio Mamanguape apresentou gradual adensamento populacional. Mesmo assim, o sistema concelhio da Capitania da Paraiba permaneceu inalterado até a década de 1760 , com uma única câmara e termo na cidade da Paraíba, na Freguesia de Nossa Senhora das Neves. A outra freguesia era a de Mamanguape, criada no século 17 sob a invocação de São Pedro e São Paulo, mas sem vilas ou cidade. Cabe-nos ressaltar que a concentração municipal na cidade da Paraíba, com seu vastíssimo termo, permaneceu por longo tempo a despeito do povoamento doutras regiões, como os sertões, onde se instalaram fazendas de gado com importante papel na economia regional, e as demais várzeas do litoral.

A partir de meados de Setecentos, a formação territorial e o equilíbrio de poderes foram alterados completamente com a criação de nove vilas, dentre elas a de Monte-mor, fundada em 1762, e tornada sede da Freguesia de Mamanguape. ${ }^{12}$ Os vereadores da Cidade, claramente insatisfeitos com a criação das novas vilas, sentiram as mudanças na balança de poderes da Capitania, sobretudo de um ponto de vista fiscal, pois houve uma redução da arrecadação em virtude da diminuição do termo da 
Escrita em câmara a 28 de julho de 1766, os edis da cidade da Paraiba queixaram-se ao secretário de Estado Francisco Xavier de Mendonça Furtado pela aplicação da ordem de criação das vilas, que, segundo os mesmos, havia sido feita em detrimento da "sempre leal Cidade da Parayba", tendo em vista a redução excessiva de seu termo. Cf. AHU - Paraiba, doc. 1800 (Paraiba, 21/ jul/1766).

14

Sobre o minguado sucesso da integração das comunidades autóctones à sociedade colonial, cf. o estudo supracitado de CARVALHO, Juliano Loureiro de. Op. Cit., p. 133.

15

No início do século 19, o viajante Henry Koster passou pelo rio Mamanguape, notando-o em uma época de sequidão, mas não deixou de observar o fluxo de mascates e a posição estratégica da povoação: "[...] na povoação de Mamanguape, situada à margem de um rio seco. É um lugar florescente [...]. 0 rio é escasso elemento de vantagem para o povoado, mas o lugar é convenientemente escolhido, entre Goiana e Rio Grande, como um quartel general para os mascates, homens úteis, industriosos e, no País, geralmente probos. Eles partem para suas excursões diárias e podem voltar para dormir à noite" (KOSTER, Henry. Viagens ao Nordeste do Brasil. Tradução, Prefácio e Comentários de Luís da Câmara Cascudo. 12 ${ }^{\mathrm{a}} \mathrm{ed}$. Rio de Janeiro; São Paulo; Fortaleza: ABC Editora, 2003, p. 109, grifos nossos).

16

AHU - Paraiba, doc. 2326 (Paraiba, 19/ mai./1795, grifos nossos).

17

MELLO, Evaldo Cabral de. A ferida de Narciso. Ensaio de história regional. São Paulo: Editora SENAC/SP, 2001, p. 53.

18

Cf. AHU - Paraiba, doc. 2457 (30/out/1798).

19

CERTEAU, Michel de. A invenção do cotidiano. Artes de fazer. $13^{\text {a }}$ ed. Trad. de Ephrain F. Alves. Petrópolis: Vozes, 2007, p. 174. municipalidade. ${ }^{13}$ Por sua vez, essa reforma territorial também se vinculou a uma tentativa da Coroa de integrar os antigos aldeamentos à sociedade colonial em um contexto pós-expulsão dos jesuitas, numa nítida política de construção de vassalagens junto às populações indígenas. No caso da vila de Monte-mor, em Mamanguape, foram transferidos para seu termo os aldeamentos Boa Vista, Campina Grande e Brejo, além do Preguiça, já instalado em sua área. ${ }^{14}$

Ao fim do século 18, o vale do Mamanguape, em especial na região de fundação da vila de Monte-mor, destacara-se também pela expansão produtiva do açúcar e do algodão em áreas antes dominadas apenas pela pecuária. Por essa época, as exportações dessas fazendas da região ombreavam aquelas das várzeas do Paraíba. Além disso, intensificou-se a extração de madeiras para a construção civil e naval, marcenaria e tinturaria. ${ }^{15}$ Com representação camarária, peso político e interesses próprios, o dinâmico movimento colonizador das ribeiras do Mamanguape, encabeçado pela nova vila de Monte-mor, fez daquela região uma zona relativamente independente da bacia do rio Paraiba, permitindo a composição de outras centralidades na Capitania, além daquela representada por sua desgastada sede administrativa. 0 comércio exportador era o mote de sua prosperidade. Assim, dava nota o capitão-mor Mello e Castro:

Recebo a muito respeitável ordem de Vossa Magestade datada de 10 de Julho passado em que me ordena suspender as prohibições que se dectinha posto de saírem os efeitos de Mamanguape [...] para o porto de Pernambuco e que faça registar nesta Camera [...] de Montemor a mesma Real Ordem. ${ }^{16}$

Após trinta anos tentando obstaculizar os descaminhos da Fazenda Real e os circuitos mercantis entre a Paraíba e o Recife, sob a alegação dos danos causados aos cofres da combalida Capitania e do reforço da sujeição a Pernambuco em virtude do desânimo dos negociantes da praça da Paraíba, Jerónimo de Mello e Castro era, finalmente, desacreditado pela própria Coroa portuguesa. Ao final de Setecentos, ao menos pelos idos de 1795, o tema do comércio era resolvido em favor das redes de negócios que cruzavam as fronteiras das capitanias do Norte rumo ao porto do Recife. Esse entreposto comercial era, mais uma vez, fortalecido, confirmando uma tendência que vinha dos tempos flamengos. ${ }^{17}$ Porém, os negócios de elites locais da Paraiba também foram protegidos pela decisão da rainha. Sem 0 primordial apoio da Coroa, Jerónimo de Mello e Castro perdera esta bataIha, uma de suas principais bandeiras enquanto capitão-mor da Paraiba: a defesa do comércio pela cidade da Paraiba como fator determinante para a autonomia político-econômica da Capitania.

Obviamente, nem todos concordavam com suas conclusões sobre a economia naquelas paragens. Poucos anos depois, envelhecido e isolado, morreria o capitão-mor da Paraíba em $1797 .{ }^{18}$ Não obstante, a morte (política) de Jerónimo de Mello e Castro não constitui o final de nossa história, muito ao contrário, ela nos obriga a seguir os sinais mais remotos, procurando os "jogos dos passos [que] moldam espaços" e que "tecem lugares", como ensinou Michel de Certeau, investigando, pelo retorno das práticas e pelas reservas com as totalizações do espaço "geométrico" ou "geográfico", as relações mantidas entre as heterogêneas elites das capitanias do Norte na segunda metade de Setecentos, e que sinalizam para a manutenção de negócios intracoloniais entre Paraíba e Pernambuco, razão precípua da ira do governador morto! ${ }^{19}$ 
20

Uma análise criteriosa dos dados do comércio português na época fugiria de nossos propósitos neste artigo, mas, para mais detalhes, cf. ALDEN, Dauril. El Brasil colonial tardio, 1750-1808. In.: BETHELL, Leslie (ed.). Historia de América Latina. 3. América Latina Colonial: Economía. Barcelona: Editorial Crítica, 1990, p. 351. Ver também ARRUDA, José Jobson de Andrade. O Brasil no comércio colonial. São Paulo: Ática, 1980.

21

ALDEN, Dauril. Op. Cit., p. 350-51.

22

"Como consecuencia del aumento de contrabando de importación de bienes manufacturados extranjeros, y del creciente valor de las exportaciones coloniales debido a un mercado europeo excepcionalmente fuerte, Portugal se encontró en la indeseable, y desde la perspectiva de los oficiales de la corona, absurda posición de tener uma balanza de pagos adversa con importantes partes de Brasil" (ALDEN, Dauril. Op. Cit., p. 352)

23

Segundo Alden, esse periodo teve seu término com a chegada da família real portuguesa ao Rio de Janeiro e o consequente fim do pacto colonia

24

PEDREIRA, Jorge Miguel. Estrutura industrial e mercado colonial. Portugal e Brasil (1780-1830). Lisboa: Difel, 1994.

25

DIAS, Maria Odila Leite da Silva. A interiorização da metrópole e outros estudos. São Paulo:

Alameda, 2005, p. 262.
0 cenário imperial em finais de Setecentos

No cenário imperial português, as três derradeiras décadas de Setecentos, bem como os anos iniciais da centúria seguinte, período que corresponde aos reinados de d. Maria I e de seu filho, d. João Vl, assinalaram a consolidação de um percurso histórico importante: a inversão colonial cujo ápice fora atingido quando a corte portuguesa cruzou o Atlântico em direitura da cidade do Rio de Janeiro, em 1808. Antes disso, o imprescindivel papel do Brasil no conjunto do Império era reconhecido por todos, até mesmo por aqueles que buscavam obliterar tal posição, pondo em "ordem" uma desequilibrada relação colônia-metrópole" em fin-de-siècle, a exemplo do secretário Martinho de Mello e Castro. A despeito da precariedade dos dados, é certo que, ao longo da centúria llustrada, a participação do Brasil no comércio exterior português cresceu exponencialmente e o seu volume simplesmente quadruplicou entre 1789 e $1807 .{ }^{20}$ Este periodo presenciou uma reversão histórica da balança comercial de Portugal com seus principais parceiros, a Inglaterra e a França, motivada, sobretudo, pelo incremento dos produtos brasileiros. Segundo Alden,

Desde principios de siglo hasta 1791 ese balance había sido siempre ampliamente favorable a Inglaterra, pero desde 1791 hasta 1810 cambio substancialmente en favor de Portugal. De los productos que Portugal envió a Gran Bretaña durante esas dos décadas, el 35,7 por 100 eran de origen brasileño. De forma similar, los términos del comercio entre el reino y otro cliente importante, Francia, también variaron a favor de Portugal a principios de la década de 1800, principalmente debido a las grandes compras francesas de cacao, café, algodón, índigo y azúcar brasileños. ${ }^{21}$

Porém, de acordo com o reconhecido brasilianista, o contrabando tentou prejudicar esses ganhos, pois era apontado como a causa principal de um danoso desequilibrio nas relações comerciais entre o reino e sua principal possessão ultramarina, uma vez que o aumento do volume de produtos brasileiros nas exportações lusas foi seguido da diminuição das importações de bens manufaturados pela América Portuguesa, transformada num mercado valioso para dezenas de barcos ingleses que por aqui pousavam para comerciar ilegalmente. ${ }^{22}$

Mesmo assim, no chamado colonial tardio - periodo entre o auge da extração aurifera, seu consequente declínio e o retorno às formas tradicionais da riqueza colonial assentes, sobretudo, na agricultura de exportação ${ }^{23}$ - Portugal beneficiou-se grandemente do dinamismo da economia colonial e, apesar de ocupar uma posição de intermediário entre os produtos americanos e os mercados europeus, lucrou seja por meio de seus homens de negócio, que, além de agenciarem o ingresso das commodities brasileiras no mercado europeu, arremataram os valiosos contratos de impostos e compraram as ações das companhias de comércio pombalinas, seja por meio dos estímulos ao efêmero surto industrial metropolitano que, segundo uma copiosa historiografia portuguesa, não conseguiu sobreviver à abertura dos portos de $1810 .{ }^{24}$

De um jeito ou de outro, o fato é que, na segunda metade do século 18 , o Brasil tornou-se o comprador de $78,4 \%$ dos gêneros metropolitanos ${ }^{25}$ e, entre 1797 e 1805, os panos lusitanos exportados para diferentes partes do Império figuravam entre os mais valiosos do conjunto de exportações do reino. Isto era garantido pelo exclusivo comercial defendido ferrenhamente pela Coroa, tendo em vista que, como endossa João Fragoso, "esse protecionismo garantia, nas 'colônias', um mercado privilegiado para os pro- 
FRAGOSO, João. A noção de economia colonial tardia no Rio de Janeiro e as conexões econômicas do Império português: 1790-1820. In: FRAGOSO, João; BICALHO, Maria Fernanda e GOUVÊA, Maria de Fátima (orgs.). $O$ Antigo Regime nos Trópicos: a dinâmica imperial portuguesa (séculos XVIXVIII). 2a reimpressão, Rio de Janeiro: Civilização Brasileira, 2010, p. 321.

27

Estudos clássicos demonstraram a importância das conexões intercoloniais na formação do mundo atlântico português, a exemplo de ALENCASTRO, Luiz Felipe. 0 trato dos viventes: formação do Brasil no Atlântico Sul. São Paulo: Companhia das Letras, 2000 e LAPA, José Roberto do Amaral. A Bahia e a Carreira da Índia. Ed. Facsimilada. São Paulo: HUCITEC/ Unicamp, 2000.

28

FRAGOSO, João. A noção de economia, Op. Cit. p. 324.

29

SAMPAI0, Antônio Carlos Jucá de. Na Encruzilhada do Império: hierarquias sociais e conjunturas econômicas no Rio de Janeiro (c 1650 - 1750). Rio de Janeiro: Arquivo Nacional, 2003.

30

Cf. SOUZA, George Felix Cabral de. Elite y ejercicio de poder en el Brasil colonial: la Cámara Municipal de Recife (1710-1822). 2007. Tese (Doutorado em Fundamentos da Pesquisa Histórica), Universidade de Salamanca 2007, especialmente, capítulos 6 e 7 .

31

FERREIRA, Roquinaldo. Cross-Cultural Exchange in the Atlantic World:Angola and Brazil during the Era of Slave Trade. New York: Cambridge University Press, 2012

32

RUSSEL-WOOD, J. A. Centros e Periferias no Mundo Luso-Brasileiro, 1500-1808. Revista Brasileira de História, vol. 18, n 36. São Paulo, 1998. As redes intracoloniais foram recentemente estudadas no interessante trabalho de GIL, Tiago Luis. Coisas do caminho. Tropeiros e seus negócios do Viamão à Sorocaba (1780-1810). 2009. Tese. (Doutorado em História Social). Instituto de Filosofia e Ciências Sociais, Universidade Federa de Rio de Janeiro, Rio de Janeiro, 2009

33

FRAGOSO, João Luis. Potentados locais e circuitos imperiais: notas sobre uma nobreza da terra supracapitanias, no Setecentos. In: MONTEIRO, Nuno G.; CARDIM, Pedro e CUNHA, Mafalda S. da (orgs.). Optima Pars. Elites Ibero-Americanas do Antigo Regime. Lisboa: ICS, 2005. As redes intracoloniais foram recentemente estudadas no interessante trabalho de GIL, Tiago Luis. Coisas do caminho. Op. Cit.

34

Ou "ressurgimento agricola", como preferem autores como SCHWARTZ, Stuart. Segredos internos. São Paulo: Companhia das Letras/CNPq, 1988 , p. 342-344 dutos portugueses e para as reexportações europeias intermediadas pelas praças reinóis". 26

Não obstante, como alertava Martinho de Mello e Castro, nesta centúria, os negócios intra e intercoloniais também se fortaleceram, confirmando uma tendência que adivinha dos Seiscentos e ligando as franjas do Império português através de redes que conectavam gentes, fortunas e sociabilidades entre sociedades reconhecidamente distintas, como eram a América Portuguesa, a África e o Estado da Índia. Estas conexões asseveraram a existência de um Império comercial que, nalgumas vezes, poderia prescindir da intermediação de Lisboa, embora a sede da metrópole continuasse sendo o principal palco político do Império, lugar de definição de estratégias de gestão dos territórios coloniais e do exercício da centralidade régia. ${ }^{27}$

Neste sentido, "as práticas político-econômicas do Antigo Regime luso, espraiadas pelo mare lusitano", como sugeriu Fragoso, combinadas com cadeias de negócio que interligavam negociantes coloniais e reinóis, oficiais da Coroa que gozavam de liberdades e isenções diversas, e escravizados que cruzavam os oceanos sendo muito mais que "mercadorias-vivas", "insinuam que o Império luso era mais que uma simples entidade político-administrativa com sede em Lisboa, sendo, em realidade, um espaço econômico com alto grau de refinamento". ${ }^{28}$

Em Setecentos, um cenário mercantil amadurecido se confirmou, conferindo protagonismo ao Atlântico Sul e elevando o Rio de Janeiro ao nível de sua principal praça comercial, ${ }^{29}$ jamais prescindindo, porém, de tradicionais praças americanas como Salvador e Recife, que passaram a integrar um circuito de comércio por cabotagem que interligava as capitanias do Norte ao rio da Prata, passando pelo porto carioca e pelas praças africanas, e permitia sólidas parcerias entre homens de negócio dos três maiores portos da América Portuguesa. ${ }^{30}$ No entanto, se o comércio intercolonial e as conexões entre Brasil, África e Ásia receberam a copiosa atenção de estudos magistrais, desde o inimitável clássico de Charles Boxer, Salvador de Sá and the Struggle for Brazil and Angola, 1602-1686 (1952), passando José Roberto do Amaral Lapa e Luiz Filipe de Alencastro, até a recente história atlântica de Roquinaldo Ferreira, ${ }^{31}$ as conexões intracoloniais da América Portuguesa ainda representam um campo aberto de estudos e denunciam a variedade das relações centros-periferias existente por essas plagas - uma verdadeira "caixa de Pandora", como assinalou A. J. Russel-Wood. ${ }^{32}$

Por conexões e redes intracoloniais compreendemos, sobretudo, os intercâmbios sociais, como os casamentos e parentescos entre elites senhoriais e negociantes, os jogos políticos que poderiam (ou não) perpassar os meandros da administração colonial, e os negócios que desconsideravam as fronteiras político-administrativas entre as capitanias. Estas conexões permitiram a construção de capitalidades e, mais que isso, atenuaram os limites impostos pelas intempéries da distância e pelos precários caminhos da América Portuguesa, erigindo territorialidades supracapitanias, como indicou João Fragoso. ${ }^{33}$ Nas capitanias do Norte, em finais de Setecentos, estas networks, há muito existentes naqueles territórios, foram corroboradas por um contexto de expansão colonial, marcado, sobretudo, pelo "renascimento agrícola", ${ }^{34}$ no qual, além do açúcar (principal produto das exportações brasileiras, mas que passara por intensa crise de preços ao longo do século, recuperando-se nos anos 1780) e do tabaco, outros 
35

POLANYI, Karl. A grande transformação. Rio de Janeiro: Campus, 1980.

36

Sobre a chamada guerra dos Mascates, cf. MELLO, Evaldo Cabral de. A fronda dos mazombos. Nobres contra mascates. Pernambuco (16661715). São Paulo: Companhia das Letras, 1995. A conjuntura pós-restauração nas capitanias do Norte, que não é objeto deste artigo, é, contudo, fundamental para a compreensão do acirramento das tensões entre negociantes da praça do Recife e a nobreza da terra de Pernambuco. Neste sentido, endossa Mello, "Não se tratava apenas do conflito entre credores urbanos e devedores rurais. Também no período ante bellum, os senhores de engenho endividavamse pesadamente com os mercadores, sem que se desembocasse na guerra civil ou sequer nas tensões que a precederam. A coisa ia muito mais longe. Enquanto o comércio da Nova Lusitânia, dominado pelos cristãos-novos, nomádicos e cosmopolitas, não chegara a arraigar-se na capitania, os mascates, cristãos-velhos de origem humilde, desembarcavam do fundo de suas aldeias do norte de Portugal com o ânimo de se estabelecerem definitivamente, e embora a principio se dedicassem apenas aos afazeres mercantis, mais cedo ou mais tarde pretenderam partilhar o poder local" (MELLO, Evaldo Cabral de. Rubro Veio. 0 imaginário da restauração pernambucana. $3^{\text {a }}$ ed. São Paulo: Alameda, 2008 p. 152).

37

A esse respeito, cf. SOUSA, Avanete Pereira. Poder local, cidade e atividades econômicas (Bahia, século XVIII). 2003. Tese (Doutorado em História Econômica), Faculdade de Filosofia, Letras e Ciências Humanas, Universidade de São Paulo, 2003.

38

MELLO, Evaldo Cabral de. Rubro Veio, Op. Cit., p. 153.

39

MELLO, Evaldo Cabral de. A ferida de Narciso, Op. Cit., p. 67.

40

SAMPAIO, Antônio Carlos Jucá de. A produção política da economia: formas não-mercantis de acumulação e transmissão numa sociedade colonial (Rio de Janeiro, 1650-1750). Topoi

- Revista do Programa de Pós-Graduação em História Social da UFRJ, vol. 4, n 7, jul/dez/2003.

41

AHU - Paraiba, doc. 2336 (19/mai/1795). produtos passaram a integrar o now hall do comércio atlântico português, como o algodão, o anil, o cacau e até o café.

É, portanto, na conjuntura do colonial tardio, a última fase da experiência colonial brasileira, que procuraremos inserir nossa análise acerca dos circuitos mercantis que conectavam as capitanias do Norte entre si e ao restante do Império, considerando a construção política da economia em sociedades de Antigo Regime nas quais a ideia de um mercado capitalista e impessoal, dirigido exclusivamente por critérios econômicos, ainda não possuía sentido pleno. ${ }^{35}$

\section{Uma questão de sobrevivência}

A segunda metade de Setecentos presenciou sucessivos embates no tocante ao comércio na Paraiba. No entanto, se notamos que as vozes e os passos dos envolvidos nos litígios trilharam diferentes percursos em sua atuação, como a cidade da Paraiba, as câmaras municipais, a praça do Recife e até mesmo o Paço; não é menos verdade que os interesses em causa não se resumiam às oposições entre oficiais reinóis e colonos, ou ainda, comerciantes versus produtores e senhores de engenho, como ocorrera noutras conjunturas, notavelmente por ocasião da guerra dos Mascates (1710-11), cujo cenário particular, construído pelos anos de ocupação holandesa e posterior restauração do domínio português, asseverou as rivalidades entre mascates e mazombos. ${ }^{36}$

É certo que nas capitanias do Norte a polarização entre negociantes e nobreza da terra demorou a se exaurir, destoando do restante da América Portuguesa, sobretudo em áreas onde a integração entre as duas camadas se processou já nos Seiscentos, como foi o caso da Bahia. ${ }^{37}$ No entanto, finalizada a guerra civil ainda na primeira década de Setecentos, a relativa estabilidade da centúria tratou de aplacar (ou camuflar) os extremismos. Finalmente, "[...] para a nobreza da terra não restava alternativa após a débâcle da guerra dos mascates". ${ }^{18}$ Neste sentido, tal como notara Evaldo Cabral de Mello, ao final do século 18, boa parte das barreiras sociais erguidas entre as elites senhoriais das capitanias do Norte e os negociantes, sediados no Recife, haviam sido levantadas, ${ }_{1}^{39}$ sendo possivel, inclusive, identificar expressivas alianças que mesclavam os assuntos tipicamente financeiros com os matrimônios e o controle sobre os cargos da governança, assegurando o enriquecimento privilegiado e o status das "melhores famílias".40

Retornando ao nosso ponto de partida - a determinação régia da liberação de comércio entre a Paraiba e Pernambuco em $1794^{41}$-, ela fora a resposta da Coroa portuguesa aos repetidos apelos dos produtores e senhores de engenho das várzeas do rio Mamanguape e seu entorno para que 0 governador da Paraiba interrompesse as apreensões de carregamentos que seguiam para o porto do Recife. Pelos idos de 1791, o cenário era acirrado, como se observa na carta do suplicante Antônio da Cunha Vasconcelos, morador do distrito da Paraiba, ao governador de Pernambuco, a quem pediu socorro,

[...] no Engenho Pacatuba de onde he mais perto o Caminho do carreto das Caixas para o porto da Bahia da traição do que para o Trapixe da Cidade da Parayba; e que mandando as suas caixas para o dito porto para as fazer embarcar para este porto do Recife aonde tem maior conveniência na venda dellas, Ihe embarasa o embarque o Comandante da Bahia da Traição por despacho do Coronel Governador ou Doutor Ouvidor Geral daquella Comarca a requerimento do Contractador dos subsídios dos Açucares, que para embarazar ao Suplicante e aos maiz lavradores de Açúcar 
42

AHU - Paraiba, doc. 2240 (15/jun/1791), grifos nossos.

43

O ouvidor-geral da comarca da Paraíba, Dr. António Filipe Soares Brederode, português, foi alvo de uma série de denúncias de improbidade administrativa, prática de comércio ilícito e crimes variados na Capitania da Paraíba. Muitas dessas denúncias partiram do próprio governador, Jerónimo de Mello e Castro. 0 referido ouvidor foi objeto do interessante estudo de trajetória de PAIVA, Yamê Galdino de. Vivendo à sombra das leis: António Soares Brederode entre a justiça e a criminalidade. Capitania da Paraiba (1787-1802). 2012. Dissertação (Mestrado em História), Universidade Federal da Paraíba, João Pessoa, 2012

\section{4}

AHU - Paraíba, doc. 2240 (15/jun/1791).

Segundo o relatório do governador de

Pernambuco Jose Cezar de Menezes (1774-1787)

por essa época existiam no vale do Mamanguape cerca de quatro engenhos de açúcar, enquanto

que, no mesmo período, as várzeas do rio Paraíba possuiam dezessete engenhos. 0 diferencial do Mamanguape residia, sobretudo, em sua capacidade produtiva diversificada, que abarcava desde 0 açúcar, o algodão e o gado até às culturas de subsistência, como a mandioca, e as madeiras de construção. De todo modo, são muito escassos os dados referentes ao Mamanguape, em comparação com aqueles do vale do Paraiba. Cf. JOFFILY, Irêneo. Notas sobre a Parahyba. Fac-símile da primeira edição publicada no Rio de Janeiro, em 1892, com prefácio de Capistrano de Abreu. Brasilia: Thesaurus Editora, 1977, p. 236-255.

45

Sobre o comércio na cidade da Paraíba e o tema dos descaminhos na arrecadação das receitas da fazenda real, cf. CHAVES JR., José Inaldo. As duras cadeias, 0p. Cit., sobretudo os capitulos 2 e 4. daquela Comarca o transportarem os seus effeitos para este porto do Recife aonde os Açúcares lograo presentemente mayor valor, para o fim de os poder elle Contractador, e os Comerciantez daquela cidade comprar por diminuto presso [sic], e em prejuízo dos suplicantes [...]. ${ }^{42}$

A disparidade de interesses era notória. 0 referido produtor de açúcar, sentindo-se lesado pelas suspensões de carregamentos realizadas pelo comandante da baía da Traição, porto ao norte do rio Mamanguape, pedia a liberação do transporte das cargas para o porto do Recife, onde possuía maior conveniência no transporte e nos preços. Interessante notarmos que o suplicante desconhecia donde partira a referida proibição; supunha que fosse uma ordem ou do governador da Paraíba ou do ouvidor-geral da comarca, à época o Dr. António Soares Brederode..$^{43}$ Todavia, nas queixas de António da Cunha Vasconcelos, destacamos ainda a indicação dos tratos comerciais e financistas coadunados na praça da cidade da Paraiba, que, ao que tudo indica, logravam o apoio e ação favorável do capitão-mor Jerónimo de Mello e Castro.

Muito além de uma mera disputa entre os senhores de engenho, lavradores de cana e do algodão e o governador da Capitania, tratavase, isto sim, de um confronto com os contratadores da cidade da Paraíba que, segundo o suplicante, ao forçarem o escoamento das produções do Mamanguape para aquela praça, além de recolherem os tributos por lá arrematados, compravam as fazendas por baixo preço, pondo em flagrante desvantagem os produtores rurais. Noutro requerimento, também destinado ao governador-general de Pernambuco, à época o general Tomás José de Melo (1787-98), "o Capitam João Alves Chanches Massa, o ajudante Miguel Angelo da Silva Bezerra e o Capitam Joze Angelo da Cruz Marques, senhores de Engenhos maiores na Freguesia de Mamanguape", solicitaram a sua intermediação e explicaram a necessidade de "remeterem para esta Praça [do Recife] as Caixas que fabricão pela utilidade que percebem de as transportarem nos Barcos sem mais dispeza de Condução", alegando, ainda, que "o contratador do dízimo do asucar daquela Capitania [de Pernambuco]", por exemplo, sempre teve procurador em Mamanguape "para cobrar o subsídio que lhe pertence".44

Claro que, ao defenderem o pagamento do tributo do açúcar feito ao contratador de Pernambuco, os senhores de engenho da freguesia de Mamanguape estavam a desafiar os intentos do governador da Paraiba que, peremptoriamente, denunciava o prejuizo que tais "desvios" representavam à fazenda real. Por outro lado, os contratos dos subsídios e dízimos dos açúcares firmados na cidade da Paraiba eram igualmente lesados, minorando os ganhos dos arrematantes da cabeça da Capitania. Neste sentido, a anexação de 1756 intensificou, a nosso ver, um problema de longa data: aonde deveriam ser cobrados os impostos das exportações e importações da Capitania, principais rendas de seus cofres? Ademais, é certo que a cidade e praça da Paraiba possuía um corpo de negociantes insatisfeito, pois, ao arrematarem contratos como o do subsídio do açúcar, terminavam por amargar grandes perdas, frutos nefastos da condução das produções ao Recife. ${ }^{45}$

$\mathrm{Na}$ lista de devedores da Provedoria da Fazenda no ano de 1790 figurava o nome do contratador da cidade da Paraíba e seus engenhos, Ignácio Luis da Graça, que, devido ao volume de dívidas e recusa de pagamento, corria "expediçam contra os benz do rematante". Ignácio Luis da Graça possuía como seu fiador outro devedor de vultosa soma, o sr. Manoel Vieira 
47

AHU - Paraiba, doc. 2257 (Vila de Monte-mor, o novo, 20/abr/1792).

48

Segundo Mozart Vergetti de Menezes, "as taxas sobre a exportação do açúcar, bem como o imposto da dízima se prestavam às obras da Fortaleza do Cabedelo, à folha militar, e ainda ajudavam no pagamento do governador". Acerca dos constantes atrasos da Provedoria de Pernambuco no repasse anual dos 20 mil cruzados da arrecadação da dízima da Paraiba, cf. MENEZES, Mozart Vergetti de. Colonialismo em ação: fiscalismo, economia e sociedade na Capitania da Paraiba (1647-1755). 2005. Tese (Doutorado em História Econômica), Faculdade de Filosofia, Letras e Ciências Humanas, Universidade de São Paulo, São Paulo, 2005.

49

AHU - Paraiba, doc. 2257 (Vila de Monte-mor, o novo, 20/abr/1792, grifos nossos).

50

Acreditamos que a referência à "Capitania", neste caso, diga respeito, especificamente, a Cidade da Paraiba e sua capitania de ordenanças. Segundo Graça Salgado, os termos capitão-mor e capitania (região de atuação de um capitãomor) tiveram significados diferentes ao longo do periodo colonial. Em 1570, fora criado o cargo de capitão-mor-de-ordenanças (também chamado de capitão-mor), que era o chefe de armas de companhias militares de ordenanças de cada vila e cidade. Cf. SALGADO, Graça (coord.). Fiscais e meirinhos: a administração no Brasil colonial. Rio Janeiro: Nova Fronteira, 1985, p. 99, 164. Assim, para Juliano Loureiro de Carvalho, "dentro da Capitania da Paraiba (circunscrição maior) terminariam por serem criadas algumas pequenas capitanias de ordenanças (circunscrições menores, de caráter militar) na primeira metade do século XVIII, que continuariam existindo na segunda metade do século" (CARVALHO, Juliano Loureiro. Op. Cit., p. 57).

51

AHU - Paraiba, doc. 2240 (Paraiba, 15/jun/1791). 52

Cf. OLIVEIRA, Elza Régis. A Paraiba na crise. 0p. Cit., p. 170-71. da Silva, contratador na praia de Lucena. Ao notar o Adjunto a inexistência de bens suficientes para confisco, tanto do fiador quanto do arrematante, os membros da Junta da Fazenda de Pernambuco ordenaram "deste nova fiança em prazo breve", de modo que pudesse arcar com sua dívida. ${ }^{46}$

Acerca do pagamento do subsídio do açúcar, a argumentação dos produtores das ribeiras do Mamanguape era coerente com o confuso cenário jurisdicional dos anos de anexação (1756-99). Ora, sendo a Paraíba subordinada ao governo de Pernambuco, deveria este remeter os saldos da arrematação da cobrança dos contratos reais aos cofres daquele. Na visão nada ingênua dos suplicantes, não havia qualquer dano às receitas da $\mathrm{Pa}-$ raiba se a cobrança fosse feita em qualquer uma das duas capitanias, pois "he sabido que todoz os effeitos que vão para Pernambuco, e que fazem objeto da presente proibição, ali pagão os seos Direitos", ficando o recurso retido no "cofre do Erário de Pernambuco, de donde recebe a Paraiba 0 pagamento da Tropa, e toda a mais despeza [...]".47 Contudo, era de conhecimento comum que este repasse raramente fora feito, assim como ocorria com os 20 mil cruzados do arremate anual da dízima da alfândega da Paraiba, sob a responsabilidade da Provedoria de Pernambuco desde $1723 .{ }^{48}$

A preferência pelo pagamento dos tributos aos contratadores do Recife explicava-se por estar concatenada a um segundo argumento dos suplicantes: o transporte das caixas, pois, além de não lograrem os preços desejados por seus produtos na cidade da Paraiba, eles ainda teriam que arcar com os altos custos do percurso por terra para a capital da Capitania, e sob altas penas, atender às determinações do governador Jerónimo de Mello e Castro e os ganhos dos negociantes daquela praça. Doutra feita, o comércio pelo Recife possuía navios suficientes e à disposição, saindo em fluxo contínuo rumo à baía da Traição para transportarem os açúcares e demais fazendas da exportação e mercadejarem escravos e importados. Este argumento fica ainda mais refinado noutra carta de produtores das ribeiras do Mamanguape, dessa feita representados pelos seus oficiais da câmara da vila de Monte-mor. No ofício destinado à rainha $\mathrm{d}$. Maria I, em abril de 1792, os vereadores endossavam:

\footnotetext{
[...] ser certo que esta Villa e seus contornos sempre teve desde o seo estabelecimento a comunicação com a Villa do Recife de donde vem diversos Barcos annualmente carregar no Rio Mamanguape, vizinho da mesma Villa, a saber madeira de construção, casca de mangue, e toda a qualidade de efeito que cultivão e produz a sua cituação [sic], levando em retorno as fazendas [...] e viveres da Europa e escravos da Guiné de que necessita, e não ha memoria de que em algum tempo fossem os seus moradores constragidos a levar por terra os seus effeitos a [cidade da] Parayba [...]. ${ }^{49}$
}

Outro argumento utilizado pelos homens de Mamanguape dizia respeito ao suprimento de importados, como fazendas europeias, utensilios para a agromanufatura açucareira e escravos, comprados a preços bem melhores na praça do Recife. Segundo os suplicantes, na cidade da Paraíba, os preços eram exorbitantes, pois "não tendo a Capitania ${ }^{50}$ nececidade destes efeitos de que nunca se valeo para carga dos poucos Navios que para lá navegão".51 Pelas listas de exportação e importação do início do século 19 e demais dados sobre a produção da capitania em fins de Setecentos, publicados pela historiadora Elza Regis de Oliveira, ${ }^{52}$ fica evidente que a situação da cidade da Paraíba não era de total naufrágio econômico, como fazem crer os produtores de Mamanguape, inclusive em virtude do momento de recuperação vivido por toda a colônia em finais da centúria. 

carioca de crédito: da acumulação senhorial à acumulação mercantil (1650-1750). Estudos Históricos, Rio de Janeiro, nº. 29, 2002, p. 29.

FLORY, Rae. Bahian society in the mid-colonial period: the sugar planters, tobacco growers, merchants, and artisans of Salvador and the Recôncavo, 1680-1725. 1978. Tese (Doutorado em História), University of Texas, Austin, 1978.

57

SAMPAIO, Antônio Carlos Jucá de. 0 mercado carioca, Op. Cit., p. 30.
Entretanto, o exagero e o desmerecimento da capital foram utilizados por aqueles senhores como elementos retóricos na defesa de seus negócios, mesclados intrinsecamente com os da praça do Recife.

Por fim, aqueles lavradores, que de início pediram o auxilio ao governador de Pernambuco, concluíram suas queixas reafirmando a necessária manutenção do circuito mercantil, bem como reiterando a sua pujança e os laços sólidos com os negociantes do Recife, dizendo:

[...] e nesta consternação recorrem a Vossa Excelência para que se digne permitir aos suplicantes poderem carregar as suas caixas [de açúcar] nos barcos para com ellas satisfazerem a seos credores nesta Praça [do Recife] a quem já os prometerão e fretarão Barco que já partio para transportar, e do contrário perderão os seos effeitos, faltarão aos seos credores, ficará desanimada a lavoura por falta de suprimentos. ${ }^{53}$

$\mathrm{Na}$ visão dos produtores, a ruptura destes circuitos comerciais, envoltos em complexas tessituras financeiras, poderia quebrar a empresa agroexportadora na importante região da Freguesia de Mamanguape, dependente do crédito advindo do Recife. Como salienta Antônio Carlos Jucá de Sampaio, o sistema agrário escravista da América Portuguesa possuia uma dependência estrutural de financiamento, "especialmente no que se refere ao setor açucareiro, onde a disponibilidade de crédito e 0 investimento direto foram fundamentais para a definição de suas diversas conjunturas". ${ }^{54}$ Três fatores compósitos da sociedade colonial portuguesa explicam a sua arraigada dependência creditícia. Todos eles encontram-se, a seu modo, expressos nas falas dos agricultores e senhores de engenho de Mamanguape.

Em primeiro lugar, trata-se do controle dos fluxos monetários por parte de uma pequena elite intimamente ligada às atividades comerciais, como eram os homens de negócio do Recife, que controlavam desde 0 financiamento da produção até o seu transporte para o comprador final. 0 crédito possuía papel primordial na estruturação das sociedades de Antigo Regime, merecendo, assim, uma atenção minuciosa da parte dos historiadores. Na Suiça moderna, por exemplo, o crédito era um dos principais instrumentos na "dominação que as cidades exerciam sobre as áreas rurais circundantes, sendo o grau de endividamento do campesinato bastante elevado".55 Já no caso da América Espanhola, Sampaio destaca que as extensas redes de endividamento estavam na base do sistema comercial, mesmo em regiões economicamente periféricas, como era o caso do rio da Prata na segunda metade de Seiscentos. Não era diferente para o caso do Brasil, como o estudo pioneiro de Rae Flory (1978) constatou ao analisar a agricultura açucareira baiana, apontando para a importância dos empréstimos, responsáveis tanto pela aquisição quanto pela manutenção das unidades produtivas. ${ }^{56}$ Em segundo lugar, de acordo com Sampaio, 0 caráter agrário da sociedade colonial também era um estímulo ao mercado de crédito, já que o descompasso entre o ciclo agrário, de periodicidade anual, e as necessidades diárias por insumos e alimentos "era compensado pelo sistema de contas-correntes", no qual o comerciante adiantava ao produtor insumos e mercadorias importadas, recebendo deste, por sua vez, a hipoteca da safra futura. ${ }^{57}$

Por último, a forma de aquisição da mão-de-obra escrava, feita majoritariamente através do mercado, era o terceiro fator a vincular produção e circulação na economia colonial, uma vez que "o fato de depender do mercado para adquirir parte considerável de sua mão-de-obra contribuia 
59

Sobre as cadeias de adiantamento/ endividamento da economia colonial e suas relações com as hierarquias sociais, considerando, em especial, o caso fluminense, cf. FRAGOSO, João e FLORENTINO, Manolo. 0 arcaísmo como projeto: mercado atlântico, sociedade agrária e elite mercantil no Rio de Janeiro, c. 1790-c.1840. Rio de Janeiro: Diadorim, 1993, p. 89-100.

60

Reiteremos que não queremos com isto endossar uma suposta clivagem entre homens de negócio e proprietários rurais, como teremos a oportunidade de demonstrar. Cf. SAMPAIO, Antônio Carlos Jucá de. 0 mercado carioca, 0p. Cit., p. 45.

61

Cf. AHU - Paraiba, doc. 2257 (Monte-mor, o Novo, 20/abr/1792).

62

Resgatando os estudos de Charles Boxer sobre a importância das câmaras na constituição do Império português, Maria Fernanda Bicalho afirma: "Modelo quase universal e relativamente uniforme de organização local em todo o território da monarquia portuguesa e suas conquistas, as câmaras foram, segundo $C$. $R$. Boxer, instituições fundamentais na construção e manutenção do Império ultramarino. Elas se constituíram nos pilares da sociedade colonial portuguesa desde o Maranhão até Macau, pois garantiam uma continuidade que governadores, bispos e magistrados passageiros não podiam assegurar [...]". BICALHO, Maria Fernanda B. As câmaras ultramarinas e o governo do Império. In: FRAGOSO, João; BICALHO, Maria Fernanda e GOUVÊA, Maria de Fátima (orgs.). 0 Antigo Regime nos trópicos: a dinâmica imperial portuguesa (séculos XVI-XVIII). 2 ${ }^{\text {a }}$ ed. Rio de Janeiro: Civilização Brasileira, 2010, p. 191. Ver também BICALHO, Maria Fernanda B. As Câmaras Municipais no Império Português: o Exemplo do Rio de Janeiro. Revista Brasileira de História, vol. 18, n 36, São Paulo, 1998.

63

Cf. SOUZA, Laura de Mello e BICALHO, Maria Fernanda Baptista. 1680-1720: o império deste mundo. São Paulo: Companhia das Letras, 2000 (Coleção Virando Séculos), p. 88-7.

64

AHU - Paraíba, doc. 2257 (Monte-mor, o Novo, 20/abr/1792, grifos nossos).

65

Cf. AHU - Paraíba, doc. 2240 (Paraíba, 15/jun/1791) 66

Cf. AHU - Paraiba, doc. 2325 (Paraiba, 15/ jun/1791). para o aumento do endividamento dos setores rurais, inclusive (ou principalmente) de sua elite".58 0 sistema creditício que vinculava as ribeiras do Mamanguape, na Paraíba, à praça do Recife, envolvia, portanto, múltiplos processos de adiantamento e endividamento, desde a compra das terras e manutenção das unidades, passando pela aquisição de instrumentos de trabalho e mão-de-obra escrava, até o transporte das cargas, como tão bem explicitaram os ciosos senhores de engenho e produtores da Paraíba. ${ }^{59}$ A interrupção deste esquema representaria uma perda irreparável, já que, como bem tratou Antônio Carlos Jucá de Sampaio, no século 18, senhores de engenho e lavradores "perderam de fato o domínio sobre uma das principais chaves de sua reprodução social" - o crédito -, que passou a ser controlado por uma elite mercantil cuja atuação transatlântica era decisiva à saúde do Império e, notavelmente, dos negócios das elites senhoriais. ${ }^{60}$

\section{Uma audaciosa defesa seguida de uma faceira resposta}

Alcançavam-se os 20 de abril de $1792^{61}$ quando as queixas de lavradores de açúcar e algodão, senhores de engenho e negociantes locais do Mamanguape rumaram para o maior palco político do Império - o Paço. Utilizando um dos canais fundamentais da comunicação política na monarquia portuguesa - a câmara municipal - aqueles senhores, representados pelos oficiais da jovem vila de Monte-mor, delataram à rainha as proibições de comércio com o Recife, feitas pelo governador Jerónimo José de Mello e Castro, bem como escrutinaram os motivos pelos quais se fundava o dito capitão-mor. ${ }^{62}$

Neste sentido, Souza e Bicalho acrescentam que, solidificada por um meio de um dispositivo imemorial - o chamado direito de petição - a comunicação direta entre o monarca e seus vassalos, sobretudo por meio das câmaras, constituía um mecanismo de governança poderosíssimo, pois, além de aproximar os súditos do centro do Império, reduzindo as flagrantes dificuldades impostas pela distância, ainda garantiam à Coroa um melhor conhecimento do cotidiano das suas possessões coloniais, inclusive da ação de seus oficiais. ${ }^{63}$ Tendo em vista as recentes interceptações de barcos na baía da Traição, realizadas a mando de Mello e Castro, e os prejuízos causados à agricultura da região, os edis suplicavam um deferimento favorável da monarca. 0 ofício da câmara da vila de Monte-mor, assinado por cinco homens, parecia falar por muitos outros:

\begin{abstract}
Nós officiais do Senado da Camara da Villa de Montemor, o Novo, na Capitania da Paraiba, anexa a do governo de Pernambuco, a requerimento que nos fizeram os fabricantes de assucar dos Engenhos do Distrito da dita Villa e os Agricultores da planta de Algudão, e os Negociantes que vendem suas fazendas, e compram os ditos effeitos, por bem comum e utilidade publica [...]. ${ }^{64}$
\end{abstract}

Dos oficiais, ao menos um - Simão José de Souza -, guardava clarissimos interesses no comércio Mamanguape-Recife, pois era um dos senhores de engenho que igualmente assinaram o requerimento, anexado ao oficio da câmara e dirigido à rainha, d. Maria I, contra o capitão-mor da Paraiba. Consta ainda na representação as assinaturas de José Ângelo da Cruz Marques, um dos "senhores de Engenhos maiores da Freguesia de Mamanguape", que, no ano anterior, havia solicitado a intermediação do governador de Pernambuco no caso. ${ }^{65} 0$ referido senhor ocupava também, por esses anos, 0 importante posto de capitão-mor daquela vila, mantendo, assim, uma relação aproximada com o governador Jerónimo de Mello e Castro. ${ }^{66}$ 
SOUSA, Avanete Pereira. Poder local e autoridade camarária no Antigo Regime: o Senado da Câmara da Bahia (século XVIII). In: BICALHO, Maria Fernanda e FERLINI, Vera Lúcia Amara (orgs.). Modos de governar: ideias e práticas políticas no império português. Séculos XVI-XIX. São Paulo: Alameda, 2005, p. 319.

69 AHU - Paraiba, doc. 2240 (Paraiba, 15/jun/1791). 70 Idem.

71 AHU - Paraíba, doc. 2291 (Paraiba, 04/out/1793). 72

BICALHO, Maria Fernanda B.. Elites coloniais: a nobreza da terra e o governo das conquistas. História e historiografia. In: MONTEIRO, Nuno Gonçalo F.; CARDIM, Pedro e CUNHA, Mafalda Soares da (orgs.). Optima Pars. Op. Cit., p. 83.

73

AHU - Paraiba, doc. 2257 (Monte-mor, o Novo, 20/abr/1792).
E, por fim, aparece o nome de Gonçalo Lourenço Barboza, nomeado diretor da vila de Monte-mor em 1787, por ato do governador-general de Pernambuco, José Cezar de Menezes, ${ }_{1}^{67}$ um dos principais desafetos de Jerónimo de Mello e Castro ao longo de seu governo na Paraíba. Destarte, analisar esta querela da Paraiba Setecentista pode contribuir decisivamente no levantamento de caracteristicas importantes das elites coloniais nas capitanias no Norte, sem que tenhamos, a princípio, qualquer pretensão de compor um perfil global. De início, destacamos a heterogeneidade das nobrezas da terra nesse período que, "sobressaindo a base fundiária", conforme demonstrou Avanete Pereira Sousa para o caso da Bahia, compunhamse também de "expressivo componente mercantil e burocrático", podendo infiltrar-se em diversas esferas do poder no Império. ${ }^{68}$

0 capitão-mor José Ângelo da Cruz Marques, um dos principais da terra, era sócio de uma embarcação e metido com os tratos mercantis. ${ }^{69}$ Outro proprietário de um dos grandes engenhos do vale do Mamanguape era o capitão João Alves Sanches Massa, um dos assinantes do requerimento destinado ao governador de Pernambuco em 1791, ${ }^{70}$ mas que também mantinha relações estreitas com o comércio e o ramo financista, tendo em vista que figurava como fiador em contrato arrematado pelo capitão-mor de Pilar, Ignácio Bento D'Ávila Cavalcanti, na praia de Lucena, distrito da Paraiba. ${ }^{71}$ Neste sentido, com razão Bicalho reitera que "[...] a dicotomia comerciante versus proprietários de terras e plantadores de açúcar [...] não corresponde ao complexo e quase sempre ambíguo relacionamento entre esses segmentos".72 Para as capitanias do Norte na segunda metade de Setecentos, notadamente no caso da Paraíba, pensamos ser essa conclusão igualmente procedente.

Do mesmo modo, a presença entre os vereadores de um ocupante de cargo na administração central - o diretor da vila de Monte-mor, Gonçalo Lourenço Barboza, nomeado pelo governador de Pernambuco - aponta para as intrincadas arquiteturas de poderes que poderiam articular, de modos variados, os ofícios régios às municipalidades na colônia. Neste sentido, dois funcionários reinóis na Paraiba seguiam ordens e objetivos absolutamente distintos. Enquanto o comandante da baía da Traição cumpria a determinação do governador da Paraíba em barrar as embarcações saídas daquele porto em direitura do Recife, Gonçalo Lourenço Barboza assinava o ofício da câmara de Monte-mor contra as sobreditas medidas.

Ao rebater a defesa de Jerónimo de Mello e Castro para o escoamento da produção pela cabeça da Capitania, os edis e seus representados foram enfáticos. Em primeiro lugar, contra o argumento de que naquele "Porto da cidade da Paraíba vão todos os annos hum ou dois Navios de Portugal, e que para beneficiar caresse [sic] haver abundancia de carga", os vereadores revelaram-se mordazes ao considerar tal fundamento "frivolo", alegando, por seu turno, a relação direta que mantinham com a vila do Recife, "donde vem", não um ou dois - como denunciavam ocorrer na praça da Paraíba -, mas "diversos Barcos annualmente carregar no Rio Mamanguape.".3 Pensamos não haver palavras mais incisivas para afirmar a pouca monta que faziam do comércio pela cidade da Paraiba, onde não possuíam vínculo algum. Em segundo lugar, os oficiais atacaram aquilo que era, talvez, o principal objetivo de Jerónimo José de Mello e Castro: construir a autonomia do governo da Paraiba a partir do fortalecimento da sua capital.

He o segundo motivo em que se funda o dito Governador [da Paraíba], que da abundancia de efeitos naquelle Porto [da cidade da Paraíba] resultará maior 
74

Idem, grifos nossos.

75

Ibidem.

76

Ibidem. Acerca da instalação e atuação da Companhia de Comércio de Pernambuco e Paraiba, criada em 1759, cf. RIBEIRO JÚNIOR José. Colonização e monopólio no Nordeste brasileiro: a Companhia Geral de Pernambuco e Pernambuco (1759-1780). São Paulo: HUCITEC, 1976. No que diz respeito à cobrança das dividas da Companhia, após a sua extinção, cf. o estudo de MARQUES, Teresa Cristina de Novais. As dividas do Senhor Jácome Lumachi. Pernambuco e a Companhia Geral pombalina. Topoi - Revista do Programa de Pós-Graduação em História Social da UFRJ, Rio de Janeiro, vol. 12, 2011, p. 63-74.

77

AHU - Paraíba, doc. 2257 (Monte-mor, o Novo, 20/abr/1792)

78

FRAGOSO, João. Mercados e negociantes imperiais: um ensaio sobre a economia do Império português (séculos XVIII e XIX). História: Questões e Debates, Curitiba, n 36, p. 99-127.

79

ALDEN, Dauril. Op. Cit., p. 338. benefício ao comercio, avultando o numero de negociantes e cabedais, e por consequência em estabelecimentos e edifficios; porém este fundamento também he frivolo por ser manifesto engano pensar que o vexame de fazer por força ir aquela cidade [da Paraiba] os effeitos há de tornala [sic] opulenta [...]. ${ }^{74}$

Na missiva anexa à carta dos oficiais, lê-se uma acusação dirigida ao corpo de comerciantes da praça da Paraíba que remontava aos tempos da extinta Companhia de comércio de Pernambuco e Paraiba. Na interpretação dos de Monte-mor, os comerciantes da cidade eram poucos e fracos, unindo-se apenas segundo seus próprios interesses, que, por sinal, eram construídos sobre "velhas" práticas monopolísticas, uma vez que "quase todos são sócios de hum navio, única embarcação que há naquele porto, o qual navio posto a carga, a maior parte da sua estiva são os assucares que em pagamento, ou por compra adquirem os Administradores dos Fundos da Companhia extinta, e depoiz destes, os sócios do dito navio carregam os seos effeitos".75

Ao que nos parece, a praça da Paraiba, além da fraqueza de seu comércio e sistema creditício, teria se constituído, nestes anos, em um reduto para negociantes ligados à Companhia de comércio de Pernambuco e Paraiba, que, mesmo após o fim do monopólio em 1779, manteve sua atuação, seja na cobrança das dívidas, seja nos tratos mercantis em regime concorrencial. Neste sentido, o baixo fluxo de navios no seu porto também era associado, pelos moradores de Monte-mor, às próprias práticas exclusivistas dos seus homens de negócio, que não aceitavam o ingresso de navios estranhos,

e algum [navio] que vai aquele porto, nam he pedido por negociantes, mas sim por alguns fabricantes dos Assucares dos Engenhos vizinhos daquela Cidade, por não darem os seos assucares pelo preço que a dita praça oferece, e não os podendo embarcar pela ponderada falta de navios, recorrem a Pernambuco pedindo embarcação, o que conseguem se há carga bastante. ${ }^{76}$

Destarte, concluíram os oficiais suplicando a Sua Majestade que se dignasse a evitar que "a troco de se engroçar quatro negociantes da mesma [praça da Paraiba] se desanima[ssem] quatro mil agricultores, e a seo exemplo outros muitos a quem a emulação chama para a cultura das terras".77 Se a menção aos ditos quatro mil agricultores desagradados pelos embaraços dos negociantes da cidade da Paraiba era uma hipérbole, não se deve, contudo, desconsiderar seu valor argumentativo. É sabido, por exemplo, que entre os finais do século 18 e início da centúria seguinte, o têxtil do algodão era um dos produtos mais valiosos das exportações lusas, capitaneando o tão almejado crescimento manufatureiro do reino e dando forças à cultura algodoeira nas capitanias do Norte e no Grão-Pará e Maranhão. ${ }^{78}$

De acordo com o citado estudo de Dauril Alden, nos anos 1780 a fronteira algodoeira se estendia das áreas litorâneas ao interior seco da América Portuguesa e, embora o Maranhão tenha sido, por quatro décadas seguidas, o maior produtor da colônia, sobretudo a partir de 1800, foram as capitanias do Norte que se destacaram no cultivo da planta, que era enquadrada entre as de melhor qualidade no mundo, "más selectos e limpios que los de Maranhão".79 No início do século 19, as capitanias do Norte já ocupavam o topo da produção e comércio de algodão, favorecendo-se dos ótimos preços no mercado internacional, haja vista "la rápida expansión de la industria textil de algodón, que se estaba produciendo especialmente en Inglaterra y Francia, gracias a la revolución tecnológica, y la demanda de 
Cf. COSTA, Adailton Coelho. Mamanguape, a Fênix Paraibana. Campina Grande: Grafset Ltda, 1986, p. 49. Porém, sem avanços tecnológicos significativos na produção, o algodão do Brasil não tardou a ser suplantado pela superioridade técnica norte-americana em Oitocentos. Cf. ALDEN, Dauril. Op. Cit., p. 340.

83

AHU - Paraíba, doc. 2250 (Paraiba, 24/jan/1792). fibras de alta calidad para la manufactura de tejidos finos". 80 extraordinário progresso do algodão em Pernambuco mereceu a atenção do Bispo de Olinda, que espantou-se com o seu volume, que, nalguns anos, quase ultrapassou o açúcar. Os dados apresentados por Alden sugerem o crucial papel desempenhado pelo algodão na economia imperial e nas contas da monarquia nos estertores do Antigo Regime:

Entre 1781 y 1792 la participación brasileña en el mercado inglés de algodón crudo se incrementó desde un 5,8 hasta superar el 30 por 100. Para 1800 el algodón representó el 28 por 100 en valor de las reexportaciones portuguesas de Brasil, comparado con el 57 por 100 para el azúcar y sólo un 4 por 100 para el tabaco. ${ }^{81}$

Contudo, os impactos causados pela plantação desordenada do algodão na Paraiba foram motivo de muitas queixas do governador Jerónimo de Mello e Castro, preocupado com a produção de alimentos, em especial da farinha de mandioca, utilizada para suprimento das populações, sobretudo escrava, e das tropas pagas. Isto ocorria porque, ao contrário do açúcar que necessitava de um alto volume de investimentos, o algodão é, como dizia Câmara Cascudo, uma cultura distributiva, democrática, individual, podendo ser plantado por qualquer pequeno lavrador, caracteristicas que popularizaram a planta entre finais de Setecentos e ao longo de todo o século $19 .{ }^{82} 0$ capitão-mor Mello e Castro chegou ao ponto de culpar a exportação do algodão por "deixar dezerto hum porto, que muito antes do novo ramo do commercio do Algudão carregava sinco, e seis navios do Paíz", uma vez que sua produção era toda destinada ao Recife, oriunda sobretudo do vale do Mamanguape..$^{83}$ Tratava-se, evidentemente, de um desesperado exagero do governador, um despautério, tendo em vista que ele estava há muitos anos nas capitanias do Norte para reconhecer com acuidade o seu cenário comercial. Jerónimo de Mello e Castro queria mesmo, de forma muita capciosa, justificar suas apreensões, dessa feita não aos açúcares, mas ao produto que alimentava as fabriquetas têxteis da Europa.

\begin{abstract}
Nunca impedi a exportação do algudão, nem dos mais generoz, ainda que muitas vezes, como prezentemente, devião ser retidoz para sustentação dos habitantes, mas prezentemente a impedi na distancia de quinze legoas, para a indispensável carga dos dois navios anchorados neste Porto [da Paraiba], athe completamente se carregarem [...]. Para facilitar a carga obriguei os comerciantes dos navios, que trazem bastante cabedal, a pagarem o algodão pelo preço que corre nessa Praça, menos duzentos reis attendidos as despezas de condução, e se assim o não tivesse praticado, que poderia responder ao Ministério, na falta de apromptar tão ilimitada carga dos effeitos desta Capitania, sendo tantoz que podem carregar muitos navios. ${ }^{84}$
\end{abstract}

Doravante, embora a ordem régia de 10 de julho de 1794 mandasse sustar as proibições de comércio na Capitania, Jerónimo de Mello e Castro alegava "não haver onde recai[r] a respeitavel ordem", já que as câmaras litigantes continuavam a presenciar a franca saída dos efeitos pelas barras e praias da Paraiba. Na verdade, o ousado capitão-mor atreveu-se a julgar a referida decisão de dona Maria I oposta às ordens de 1685 e 1711, na qual faziam saber que quando houvesse navios a serem carregados no porto da Paraiba, ou a expectativa de ai pousarem, o governador retivesse as cargas afim de os abastecer. Neste sentido, Jerónimo José de Mello e Castro reconhecia ter retido, entre os anos de 1791 e 1792, "os effeitos de Mamanguape [...] enquanto em Junho, Março, Mayo e em Agosto carrega- 
86

Idem.

87

Cf. AHU - Paraiba, doc. 2240 (Paraiba, 15/ jun/1791).

Idem; ver também AHU - Paraiba, doc. 2250 (Paraiba, 24/jan/1792) e AHU - Paraiba, doc. 2326 (Paraiba, 19/mai/1795).

FURTADO, João Pinto. "Viva o rei, viva o povo, e morra o governador": tensão política e práticas de governo nas Minas do Setecentos. In: BICALHO, Maria Fernanda e FERLINI, Vera Lúcia do Amaral (orgs.). Modos de governar, Op. Cit., p. 406. 91

AHU - Paraíba, doc. 2326 (Paraiba, 19/mai/1795) grifos nossos. vão os Navios Boa Vista, Delfim, e o Bergantim Jupiter", cumprindo "com zelo e inteireza a Real ordem de Vossa Magestade". ${ }^{85}$

Eufemismos a parte, embora não tivesse havido uma proibição formal emitida pelo governador Mello e Castro - aliás, fato este que Jerónimo tratou de documentar com certidões passadas pelo administrador geral dos contratos, José Vicente Monteiro da Franca, ${ }_{1}^{86}$ e pelo provedor da Fazenda, Antônio Luis Nogueira ${ }^{87}$-, o próprio governador ironicamente reconheceu a autoria das interceptações na baia da Traição, fundamentando a medida a partir de disposições régias anteriores. ${ }^{88}$ Portanto, em sua interpretação, era impecável o seu serviço prestado a Sua Majestade.

Todavia, até aqui nada se falou do posicionamento do governadorgeneral de Pernambuco frente à exaltada querela, em especial no tocante às medidas de seu subordinado da Paraiba. Pois bem, digamos que a sua postura diante do impasse parece ter sido a "gota d'água" a minguar o empreendimento de Jerónimo de Mello e Castro na Paraiba, pois, como era de se esperar, o general Tomás José de Mello assumiu a causa dos moradores de Monte-mor e, mais que isto, defendeu os interesses dos homens de negócios sediados na praça do Recife, que não queriam amargar outros prejuizos com os confiscos de Jerónimo. Em carta à rainha d. Maria, o governador de Pernambuco alegou que as causas do capitão-mor da Paraíba "não eram atendiveis" porque:

\footnotetext{
[...] na Parahiba sem aquella prohibição sempre se carregarão os Navios que ali hião buscar carga, e se prezentemente se demorão mais em a receber, he porque os donos deles Ihe não fazem as estivas, como praticão os negociantes desta Praça; e alem disto pertendem comprar os effeitos aos lavradores, e comerciantes por preços mais diminutos do que aqui se vendem, praticando agora ainda pior porque certos de que os effeitos ali hão de hir todos, e dali não hão de sahir, em consequência da dita prohibição, oferecem por elles o preço que muito lhes parece, ao qual se sujeita 0 lavrador, ou vendedor por ter fechado o recurso do milhoramento, vindo desta forma a ter a agricultura huma grande decadência e prejuizo cauzado, tudo pelos efeitos da mencionada proibição. ${ }^{89}$
}

Claramente, as palavras de Tomás José de Melo, governador de Pernambuco, representaram um golpe de consolação na questão, pois, além de acentuarem cabalmente a sua posição sobre o comércio intracolonial nas capitanias do Norte, revelaram uma perspectiva político-administrativa plenamente integrada à noção de Império que valorizou a complementaridade de interesses entre a metrópole e a colônia. Na geração de 1790, essa perspectiva esteve sumariamente presente nas ações de figuras públicas como d. Rodrigo de Souza Coutinho e via as fronteiras internas ao mundo luso-brasileiro "antes sob o signo da 'contiguidade' que da 'ruptura'", como bem lembrou o historiador João Pinto Furtado..$^{90}$ Neste sentido, o general Tomas José de Melo afirmou ser "a exportação dos efeitos produzidos na Capitania da Paraiba hum comercio Nacional praticado entre vassalos da mesma Coroa", deferindo, portanto, que a ordem de Jerónimo de Mello e Castro fosse feita sem validade alguma, "para ficar livre aos habitantes da dita Capitania o poderem conduzir a esta Praça [do Recife] os seus efeitos".91

Uma linha bastante distinta de intervenção nos assuntos da administração colonial era postulada por homens como o conde de Assumar, nas primeiras décadas de Setecentos, e pelo secretário Martinho de Mello e Castro, morto em princípios de 1795. Segundo Furtado, nesta perspectiva, os colonos eram vistos como, "por definição, insubmissos, desleais e peri- 
92

FURTADO, João Pinto. Viva o rei, viva o povo, 0p. Cit., p. 407.

93

A respeito do parentesco entre Jerónimo e Martinho de Mello e Castro, cf. CHAVES JR., José Inaldo. Biografia e micro-história: diálogos possiveis para uma história da governança no Império português (Capitania da Parayba, c.1764 1797). Revista Cantareira - Revista Discente da Área de História da UFF, $15^{\text {a }}$ ed., julho/dezembro de 2011.

Apud NOVAIS, Fernando Antônio. Portugal e Brasil, 0p. Cit., p. 82-83.

95

AHU - Paraiba, doc. 2326 (Paraíba, 19/mai/1795).

96

Para uma discussão sobre o conjunto das ordens régias que regularam o comércio intracolonial entre Paraiba e Pernambuco, cf. CHAVES JR., José Inaldo. As duras cadeias, $0 p$. Cit., especialmente 0 capítulo 4.

97

Cf. a esse respeito o notável COUTINHO, José Joaquim da Cunha de Azeredo [1794]. Ensaio Econômico sobre o comércio de Portugal e suas colônia. Edição da John Carter Brown Library, s/d.

98

NOVAIS, Fernando Antônio. Op. Cit., p. 250. gosos". Deste modo, no trato com as possessões coloniais, o "uso de todo o peso da autoridade metropolitana, e da força [...], é tido como recurso político inerente e desejável, uma vez que só por meio da autoridade se anulam e minimizam os efeitos da descontinguidade absoluta de interesses, principal caracteristica das relações entre metrópole e colônia".92 Ao nosso ver, o capitão-mor da Paraiba, além de ser primo do referido ministro Martinho de Mello e Castro, compartilhava das mesmas perspectivas quanto ao governo das conquistas, terras onde o aumento da real fazenda e o bem comum passavam pelos maiores excessos. ${ }^{93}$

Não sem muitas idas e vindas se chegou ao final desta história com a decisão da Coroa em favor dos circuitos mercantis entre o vale do Mamanguape e o Recife. Doravante, com esta decisão pelo fortalecimento do comércio intracolonial nas capitanias do Norte destoava-se sensivelmente de orientações anteriores, a exemplo dos alvarás de 19/6/1772 e 12/12/1772 que proibiam taxativamente as trocas comerciais entre as conquistas, por ser "huma máxima geralmente recebida e constantemente praticada entre todas as nações, que da Capital, ou Metrópole Dominante, he que se deve fazer o Commercio, e Navegação para as colônias, e não as colônias entre si". ${ }^{\prime 4}$ Disposições bem mais velhas também tentaram, sem muito sucesso, vetar as rotas mercantis entre as capitanias do Norte, como as de 1685 e 1711 , mencionadas acima ${ }_{1}^{95}$ constituintes de estratégias difusas de garantia da reserva de mercado ao porto da Paraíba e, além disso, conter os desvios de receitas para a vizinha capitania ao sul. 0 cumprimento destas ordens esteve quase sempre submisso às intenções e força política dos capitãesmores da Paraiba. Em alguns contextos, estes, junto com outros oficiais da Coroa com atuação local, defenderam aguerridamente as redes de negócio com Pernambuco, muitas vezes motivados por claríssimos interesses econômicos e por suas alianças com as elites locais; noutros, porém, declararam guerra a estes contatos, como fez Jerónimo de Mello e Castro. ${ }^{96}$

Entretanto, na década de 1790, era majoritário o entendimento de que a política comercial portuguesa necessitava de reformas. ${ }^{97}$ Fernando Antônio Novais ressaltou as "aberturas dentro do sistema", analisando que, na última fase do sistema colonial, o fim dos monopólios das companhias de comércio, a supressão do estanco do sal e do contrato da pesca das baleias (1801), além de medidas pontuais de estímulo ao comércio intercolonial, representaram a opção da Coroa portuguesa por "uma linha política de abrandamento em face das condições de crise, em suma uma perspectiva reformista", reduzindo o "exclusivo colonial à sua expressão mínima nas fronteiras do sistema". Para Novais, tratava-se de assumir uma postura intermediária, entre o mercantilismo tradicional e as novas teorias econômicas. ${ }^{98}$

Mas, nos últimos anos do século 18 , se havia alguma crise, esta não se abatera sobre a América Portuguesa, que vivia um momento de prosperidade. Em Portugal, a crise era essencialmente política e revelara as dores do reformismo lusitano, devedor das orientações de Sebastião de Carvalho e Melo, mas desejoso em reinventar as bases do pacto colonial. Doutra feita, a ordem régia foi, então, emitida em um contexto no qual o incentivo ao capital mercantil e, mais que isto, a integração econômica entre as partes do Império orientavam decisivamente a política ultramarina. Em tempos do chamado "ressurgimento agrícola", a produção açucareira de Mamanguape e seu escoamento pelo porto do Recife representam a recuperação desta cultura na América Portuguesa. Pelos idos de 1761, a indústria açucareira em Pernambuco e Paraiba permanecia estacionada, com os 
99

ALDEN, Dauril. Op. Cit., p. 330.

100

Idem.

101

A esse respeito, cf. OLIVEIRA, Elza Regis. Op. Cit.

102

Cf. AHU - Paraiba, doc. 3274 (Paraiba, 06/mai/1806).

103

CARVALHO, Juliano. Op. Cit., p. 67.

104

Trata-se do mesmo sobrenome do supracitado senhor de engenho da região, o capitão João Alves Sanches Massa. Não conseguimos, infelizmente, localizar o grau desse possivel parentesco. Doravante, um detalhe interessante é que o mesmo capitão Sanches Massa, dono do engenho Pacatuba, é denunciado por Irineu Ferreira Pinto como sendo um dos líderes da reação regalista à "Revolução de 1817" na Paraiba. Cf. PINTO, Irineu Ferreira. Datas e notas para a História da Paraiba. Vol. 1. João Pessoa: Editora Universitária/ UFPB, 1977 (Documentos paraibanos, 3), p. 263. Sobre a chamada "Revolução de 1817" e seus desdobramentos nas capitanias do Norte, cf. MARIANO, Serioja Rodrigues. Gente Opulenta e de Boa Linhagem: familia, política e relações de poder na Paraiba (1817-1824). 2005. Tese (Doutorado em História), Universidade Federal de Pernambuco, Recife, 2005.

105

Sobre Jose Vaz Salgado, cf. MARQUES, Tereza Cristina de Novaes. José Vaz Salgado: a herança de um militar-mercador no Recife de meados do século XVIII. Textos de História, vol. 15, n 1, 2007. mesmos indicadores dos últimos quarenta anos. Tal situação modificou-se completamente nas três décadas seguintes e, ao final de 1777, as exportações de açúcar já tinham duplicado e o número de engenhos saltara de 268, em 1761, para 390 por essa época. ${ }^{99}$

Pernambuco e suas anexas, Bahia e Rio de Janeiro continuaram sendo as principais exportadoras do açúcar americano, muito embora outras capitanias também se destacassem, como São Paulo. No Rio de Janeiro, por exemplo, um rápido crescimento se processou, como nota Alden: "Alli, entre 1769 y 1778, el número de ingenios casi se duplicó (de 56 a 104) y la producción se elevó en un 235 por 100". 100 Contudo, o autor alerta que os benefícios desta recuperação econômica se resumiram, praticamente, ao litoral, de modo que boa parte do interior permaneceu decadente. $\mathrm{Na}$ periférica capitania da Paraiba, subordinada ao governo de Pernambuco e recém-saída de um delongado estágio de malogro econômico, resultante, sobretudo, das guerras destruidoras do século 17, das graves intempéries climáticas e da crise do açúcar na primeira metade de Setecentos ${ }_{1}{ }^{101}$ foi notável a recuperação econômica naquela virada de século, especialmente na próspera região do Mamanguape.

Os mapas estatísticos referentes aos anos de 1804 e 1805, enviados à Coroa pelo então governador da Paraíba Joaquim Raposo de Albuquerque, em 1806, dão conta de dados sobre o comércio, produção e população da capitania da Paraíba. ${ }^{102}$ Analisando tais fontes, Juliano Loureiro de Carvalho destaca que a produção do vale do Mamanguape, exportada majoritariamente pelo Recife, era "[...] compatível à da Cidade, em 1805, e mesmo à de toda a ribeira do Paraíba [...] em 1804". A região gozava ainda da vantagem de possuir grande diversidade de produtos e das relações com o Rio Grande do Norte. ${ }^{103}$ Nada mais plausivel, em nossa opinião, que o pragmatismo português tenha atuado na proteção desses negócios, bem como no aproveitamento das melhores condições de arrecadação em uma conjuntura favorável ao crescimento das capitanias do Norte.

Como um verdadeiro xeque-mate, a Coroa ordenou ao governo da Paraíba que realizasse a arrematação dos contratos do dízimo do açúcar das ribeiras do Mamanguape em separado ao restante da Capitania. Assim, em 24 de outubro de 1793, dava nota o capitão-mor Jerónimo de Mello e Castro do novo contratador, o Sr. Luiz António Alves Massa. ${ }^{104}$ No entanto, 0 mais interessante era, outrossim, o nome do seu fiador, ninguém menos que Jose Vaz Salgado, um dos maiores negociantes de grosso trato da praça do Recife! Vaz Salgado, além de ser um respeitado capitão-mor e cavaleiro da Ordem de Cristo, esteve envolvido em negócios que iam desde o tráfico com a costa africana e o comércio por cabotagem pelo Brasil, até à arrematação de contratos reais e às atividades financistas, emprestando, inclusive, para tradicionais mercadores, como os fluminenses Carneiro Leão. ${ }^{105}$

Não se pode perder de vista que, na segunda metade do século 18 , os interesses sediados na capital da Capitania da Paraíba não se confundiam com os tantos outros espalhados por outras paragens, do litoral aos sertões. Deste modo, observamos que, ao menos no caso daquelas elites do vale do Mamanguape, no litoral norte da Capitania, eram inexistentes quaisquer sentimentos de identificação com uma entidade/unidade política encabeçada pela cidade da Paraiba, tal como nos é acessível hoje. Para os senhores de Mamanguape, a anexação a Pernambuco não constituíra peso algum; pelo contrário, suas estratégias e seus negócios contribuíram para operacionalizar a política de capitanias anexadas, envolta num 
106

Cf. AHU - Pernambuco, doc. 13555.

107

Cf. AHU - Pernambuco, doc. 13533.

108

AHU - Paraiba, doc. 2372 (Paraiba, 18/nov/ant. 1796).

109

De acordo com Andrée Mansuy-Diniz, tão logo d. Rodrigo assumiu o ministério da Marinha e Negócios Ultramarinos, em 1796, "[...] pediu a todos os governadores das Capitanias informações precisas: descrição geográfica e topográfica, estatísticas da população, das produções agricolas e minerais, das exportações, impostos, rendas reais, despesas gerais da capitania, estado das tropas e milícias, das fortificações e dos armamentos etc. Pedia, também, propostas relativas a melhorias a introduzir na agricultura, comércio e finanças da Coroa. Estes dados eram o fundamento para as medidas de governação que ele queria implementar (SILVA, Andrée Mansuy-Diniz. Uma figura central da Corte Portuguesa no Brasil: D. Rodrigo de Sousa Coutinho. In: MARTINS, Ismênia e MOTTA, Márcia (orgs.). 1808 - A Corte no Brasil. Niterói: Editora da UFF, 2010, p. 139-140). complexo de relações sociais muito mais antigas nas capitanias do Norte e que remontavam ao próprio processo de conquista e ocupação territorial da região, que caminhou pari passus com a reprodução social de elites sediadas ao sul, na antiga donataria de Duarte Coelho. Neste sentido, fica evidente que a produção das territorialidades coloniais avança muito além das divisões político-administrativas do espaço eventualmente definidas pela Coroa.

0 Império português se constituiu por unidades complexas e fluídas que nem sempre se limitaram à fixidez das cartas geográficas. No caso dos espaços do antigo Norte (atual Nordeste oriental), se, por um lado, poderiamos falar em fronteiras insubmissas às tradicionais divisões em capitanias, por outro, não esqueçamos que ali os territórios, como produção, moldaram os espaços. Destarte, os negócios agrupados em torno da cidade da Paraiba, isto é, dos negociantes e contratadores por lá instalados, e que integravam os discursos "pró-autonomia" do governador Jerónimo José de Mello e Castro, revelavam a tentativa de construir uma capitalidade que, na prática, pouco funcionou até não menos os finais de Setecentos. Eram, assim, interesses localizados e não majoritários. Os embates pela afirmação da capital avançaram os Oitocentos, a despeito da desanexação ter sido decretada em 1799.

Dois capitães-mores, os sinais dos tempos e a desejada autonomia: à guisa de conclusão

Jerónimo José de Mello e Castro desapareceu em 13 de maio de 1797, acometido de moléstia que desconhecemos a origem. No dia 20 desse mesmo mês, o governador de Pernambuco enviara carta a Lisboa comunicando a morte do capitão-mor da Paraíba e pedindo providência brevíssima do novo governador. ${ }^{106}$ Não obstante, o falecimento de Mello e Castro já era aguardado, pois em 29 de março, Tomás José de Melo, general de Pernambuco, informou d. Rodrigo de Souza Coutinho do estado moribundo do governador da Paraiba, declarando que, em caso de morte, determinaria que o comandante das tropas e ouvidor itinerante assumisse interinamente o ofício vacante, até que o novo ocupante tomasse posse. Pelo que consta no ofício de Tomas José de Melo, de 29 de março de 1797, um postulante espreitava o último suspiro agonizante de Jerónimo de Mello e Castro. Era o cavaleiro professo da Ordem de Cristo Fernando Delgado Freire de Castilho, ${ }^{107}$ que, algum tempo antes, havia solicitado a mercê do governo da Paraiba. ${ }^{108}$

Uma vez morto o combalido Jerónimo de Mello e Castro, tomou o seu lugar Freire de Castilho, sendo capitão-mor até 1799, em uma conjuntura bem distinta daquela de meados de Setecentos e com a incumbência de demonstrar à Coroa a utilidade de se fazer a Paraíba novamente autônoma. 0 regimento que the foi conferido, assinado por $d$. Rodrigo de Sousa Coutinho, dava-Ihe inúmeras recomendações, de toda ordem, cobrandoIhe informações detalhadas sobre a defesa da Capitania, as condições das fortificações e corpos militares, até o estado econômico da Paraíba, suas produções, matas, comércio e população. ${ }^{109}$ Todavia, a abertura da carta trazia um objetivo primaz ao qual foi encarregado o novo governador: a Coroa desejava conhecer a conveniência de se manter a Paraiba anexa a Pernambuco, ou, enfim, fazê-la independente.

Havendo-se essa capitania da Parahiba incorporado na de Pernambuco, a que está sujeita, em consequência de uma Consulta do Conselho Ultramarino, ordena Sua 
110

PINTO, Irineu Ferreira. Datas e notas para a História da Paraíba. Edição fac-simiiliar. João Pessoa: Editora Universitária/UFPB, 1977, vol. 1, p. 180.

111

AHU - Paraíba, doc. 2372 (Paraíba, 18/nov/ant. 1796).

112

CHAVES, Cláudia Maria das Graças. O outro lado do Império: as disputas mercantis e os conflitos de jurisdição no Império Luso-Brasileiro. Topoi - Revista de História do Programa de PósGraduação em História Social da UFRJ, vol. 7, n 12, jan/jun/2006, p. 149.

\section{3}

Boa parte desse rico material histórico foi compilada na obra Datas e notas para a História da Paraiba (1908), de Irineu Ferreira Pinto, a qual utilizamos a seguir. Sobre a colaboração dos governadores do Império com os propósitos reformistas de d. Rodrigo de Sousa Coutinho, Mansuy-Diniz Silva destaca que: "Felizmente, D. Rodrigo teve a sorte de encontrar colaboradores de grande qualidade, que o entenderam, 0 apoiaram, e o aconselharam na sua acção reformadora. Eram homens formados pela universidade de Coimbra, mineralogistas, botânicos, matemáticos, que publicaram memórias na Academia Real das Ciências de Lisboa, magistrados, oficiais da marinha, governadores das Capitanias, etc. Faziam parte daquilo a que chamei há pouco a 'constelação brasileira', porque muitos deles eram nascidos no Brasil e conhecedores do seu pais. 0 professor Kenneth Maxwell chamou-Ihes Geração de 1790. Dela faziam parte José Joaquim de Azeredo Coutinho (nascido na capitania do Rio de Janeiro), que também defendia a abolição do monopólio do sal, Manuel Ferreira da Câmara (nascido nas Minhas Gerais), mineralogista distinto, e José Bonifácio de Andrade e Silva (nascido em Santos), também mineralogista. Eram homens 'esclarecidos', preocupados com o progresso do Brasil e do Império português" (SILVA, Andrée Mansuy-Diniz. Uma figura central da Corte Portuguesa no Brasil: D. Rodrigo de Sousa Coutinho. In.: Martins, Ismênia e Motta, Márcia (orgs.). 1808, 0p. Cit., p. 141).

114

Apud PINTO, Irineu Ferreira. Op. Cit., p. 197.

115

"Eu não sou inimigo da cultura do algodão, conheço que corresponde bem ao seu cultivador, mas custa-me que elle vá enfraquecendo a cultura do assucar, a principal do Brasil, e a que há de subsistir quando a do algodão já não achar terrenos virgens onde se cultivem, e chegar por isso ao período da sua decadência. Seria a desejar que estes dois ramos de cultura subsistissem e offerecessem a um tempo para que da mesma sorte pudesse subsistir o commercio, pois que podendo dar-se exportação do Brasil sem algodão, se não poderá jamais dar sem assucar" (In: PINTO, Op. Cit., p. 198, grifos nossos).
Magestade que Vossa Mercê examine com a maior imparcialidade se a utilidade que tira a Fazenda Real desta incorporação pela economia que póde resultar de não manter um governo totalmente independente, equivale aos prejuizos que póde receber seja da falta de execução das reaes ordens, seja da menos activa cobrança das dividas reaes dependentes de Pernambuco, seja de se manter um conflicto de jurisdição igualmente nocivo ao Real Serviço e aos interesses dos habitantes da capitania, que também podem receber algum veixame de um systema, que os faz dependentes para o seu commercio da praça de Pernambuco. ${ }^{10}$

Logo é de notar que as orientações do secretário de d. Maria I ao novo governador da Paraiba rompiam um silêncio mortífero de, pelo menos, quarenta e dois anos, desde quando, em 1755, o Conselho Ultramarino solicitou do então capitão-mor, Luiz António Lemos de Brito (1754-1757), um relatório no qual revelasse as condições de se manter um governo autônomo na Paraíba. Lemos de Brito, à sua época, denunciou a precariedade das rendas da Capitania e sua posição foi decisiva na conhecida tomada de decisão da Coroa. Em 1797, o questionamento metropolitano era inverso. Embora não fosse propriamente afortunado, o cenário econômico era bem mais alentador, a despeito das inconstâncias climáticas. Porém, as evasões de receitas por meio dos descaminhos das fazendas para Pernambuco, sem contar os numerosos conflitos de jurisdição, ainda perturbavam os ânimos no governo da Paraíba.

Decerto que o comportamento do capitão-mor Fernando Delgado Freire de Castilho foi igualmente decidido a mostrar as potencialidades da Capitania e os prejuízos da anexação, sobretudo para a fazenda real. Dedicou-se com esmero a esta missão, utilizando um sofisticado ferramental ilustrado, típico da geração de 1790, o qual deve ter aprendido durante sua formação em matemática e ciências naturais na Universidade de Coimbra. ${ }^{111}$ Segundo Cláudia Maria Chaves, uma das caracteristicas mais importantes dos projetos reformistas da geração de 1790 , levados a cabo nos tempos de secretariado de d. Rodrigo de Sousa Coutinho, era o destacado interesse em "ampliar os conhecimentos sobre o território americano - população, produção, comércio, cartografia, caminhos, etc. - ao propor ações de intervenção a partir de princípios fisiocráticos e liberais".112

Essa perspectiva atingiu, de modos diversos, todo o Império, inclusive áreas periféricas como a Capitania da Paraíba. Fernando Delgado Freire de Castilho, por sua vez, foi operoso nesse sentido, produzindo uma gama de relatórios e memórias sobre a agricultura, notadamente o cultivo do algodão e do açúcar, a mineração, a exploração das florestas, a produção de linho e anil e a necessidade de haver comércio livre na Paraíba. ${ }^{113} 0$ governador foi um obstinado defensor da modernização da cultura do açúcar, "livrando-o da rudez e materialidade com que é tratada"; lamentava o fato de não haver um critério de verificação das habilidades do oficio de mestre de açúcar, como se notava noutros ofícios. ${ }^{114} \mathrm{Na}$ esteira das reclamações de seu antecessor, Castilho observou os riscos da tendência, em finais de Setecentos, dos agricultores abandonarem o fabrico do açúcar, sem o qual as exportações do Brasil não subsistiriam, para se dedicarem exclusivamente ao cultivo do algodão. ${ }^{115}$

Em 1799, Freire de Castilho enviou à corte relatório com dados demográficos, naturais, administrativos e produtivos da Paraiba. Descreveu as dimensões geográficas da Capitania, sua estrutura territorial, com suas vilas e freguesias, e a administração da fazenda, a cargo de um provedor e um escrivão. Por outro lado, ele não se privou de discutir abertamente 
116

Idem, p. 207.

117

Ibidem, p. 208. Um ponto delicado da posição de Castilho a respeito do lucro monopolístico, era a sua defesa da abolição das penas contra os "commissarios volantes, requeridas pela sôfrega ambição dos negociantes e contra a manifesta utilidade da agricultura em hum paiz onde o commercio he limitado a metrópole, ao menos esses compradores concorrendo com os traficantes da terra melhorem a condição dos vendedores, a quem o Negociante da pouco, e menos de valor e talvez vende effeitos caros 0 lavrador os desbaratar e apurar dinheiro com que compre o que the não fornece" (CASTILHO apud PINTO, Op. cit., p. 208).

118

Idem.

119

Ibidem, p. 208, grifos nossos.

120

CASTILHO apud PINTO, Op. cit., p. 209, grifos nossos.

121

ROSANVALLON, Pierre. O Liberalismo econômico: história da ideia de mercado. Trad. Antonio Penalves Rocha. Bauru: EDUSC, 2002, p. 8. temas caros à Coroa no que tange ao governo das capitanias do Norte, deixando entrever as concepções políticas que norteavam seu pensamento acerca do Império português e que, pelo visto, encontrava correspondência no secretário d. Rodrigo de Sousa Coutinho. Sobre o comércio, Castilho fez uma delongada descrição do estado das práticas mercantis na Paraíba, lamentando o fato dos negociantes da Capitania serem poucos e pobres. ${ }^{116}$

Nenhuma novidade diante daquilo que já havia exasperado o finado mercantilista Jerónimo de Mello e Castro, não fossem as interessantíssimas noções que fundamentavam o discurso de Castilho. Ao lamentar a penúria dos homens de negócio da praça da Paraiba, Fernando Delgado Freire de Castilho responsabilizou a extinta Companhia Geral de Pernambuco e Paraiba pelo atraso da agricultura e pelo desânimo das trocas comerciais. Ao que nos parece, o capitão-mor era um ferrenho opositor dos monopólios e exclusivos mercantis, reiterando que "a falta de concurrencia de compradores opprime o desgraçado lavrador, que não tendo a desgraça de haver obrigado os seus effeitos a dividas carregadas de uzuras mordentissimas, tem ainda o dado na testa para vender seus effeitos pelos preços correntes, estabelecidos na miséria dos mesmos indivíduos [...]".117

Na visão do governador, o descaminho das produções para o porto do Recife era, tão somente, o resultado de um estágio de desalento dos preços provocado pela usura de comerciantes avarentos, o que obrigava os desesperados agricultores da Paraiba a levarem suas fazendas à vizinha Capitania, a despeito dos altos custos que tinham com tal transporte, tanto por mar quanto por terra. Neste caso, segundo Castilho, a praça do Recife, em proporções maiores, possuía quase os mesmos vícios daquela paraibana, "sendo tal o estado da agricultura que o commercio não só não auxilia, mas tende a extingui-la [...]".118 Em sua opinião, apenas a suspensão dos monopólios modificaria esse quadro.

Para que estes males funestíssimos se remedeem, cumpre que acuda a Mão Benefica e Poderosa de Vossa Magestade convidando por alguns de tantos meios que tem a Real Grandeza e Poder, negociantes ricos que se estabelecão aqui e possão fazer créditos mais dilatados aos agricultores desta capitania e que mandem vir directamente escravos, effeitos e instrumentos que vendão a mais cômodos preços e isto sem privilégios exclusivos [...].119

Fernando Delgado Freire de Castilho, que parecia estar atualizado acerca dos debates da literatura econômica de finais do século 18, acreditava mesmo numa progressiva redução da influência do governo nas questões ligadas ao comércio e à agricultura; assim não fosse talvez não tivesse declarado tão piamente: "Haverão riquezas e comodos da vida e será desnecessária a maior influencia do Governo que depois de bem estabelecido o commércio e agricultura só deve vigiar os abusos e não se entremetter em direcção dos proveitos particulares que geralmente são melhor entendidos e mais bem zelados de quem nelles interessa". ${ }^{120}$ As suas ideias parecem, portanto, confirmar a tese de Pierre Rosanvallon sobre a construção da noção de "mercado" em Setecentos, uma vez que, muito além de um conceito "técnico", o mercado "remetia a uma problemática implícita de regulação social e política no seu conjunto".121

Para esse teórico francês, o liberalismo econômico nasceu não apenas como uma teoria, mas representou a "reivindicação e tradução da emancipação da atividade econômica em relação à moral, devendo ser compreendido, antes de tudo, como resposta aos problemas não resolvidos 
123

WEHILING, Arno. A invenção da História: estudos sobre o historicismo. Rio de Janeiro: Editora Central da Universidade Gama Filho; Niterói: Editora da Universidade Federal Fluminense, 1994, p. 160.

124

Apud PINTO, Irineu Ferreira. Op. Cit., p. 209.

125

Idem, p. 210.

126

Ibidem, p. 212.

127

Ibidem, p. 211. Acerca da impunidade dos facínoras que encontravam alento na confusa jurisdição da Paraíba anexada, Freire de Castilho parece repetir as angustiadas palavras de ex-governador Mello e Castro: "[...] os effeitos desta rivalidade passam tão bem a opressão de quem recorre e deve o seu adiantamento, ou graça ao Governador subalterno, ainda mais são a impunidade dos mal feitores e criminosos que geralmente produzem nos orgulhosos e atrevidos o despreso do mesmo Governador, o qual sem o arbitrio das providencias repentinas, que pede huma colônia desta sorte, mortificado por ordens, encontradas, vendo talvez desapprovados os projectos mais benéficos [...]" (Apud PINTO, Op. cit., p. 211).

128

Ibidem, p. 211. pelos teóricos políticos do contrato social".122 Destarte, contrapondo-se à fixidez econômica e aos exclusivos de comércio, nocivos à agricultura, pois estimulavam a ganância desenfreada de alguns poucos, e vislumbrando 0 livre desenvolvimento das forças produtivas, cabendo ao Governo a concessão de seguridade ao livre comércio, Castilho parece confirmar que, em finais de Setecentos, "a concepção ilustrada de ciência caminhava de mãos dadas com a ideia de novas relações econômicas [...]", ainda que, na prática, se destoasse bastante destes princípios emergentes. ${ }^{123}$

Mas estas não eram as únicas ideias polêmicas do capitão-mor da Paraiba. Tal como fizera Jerónimo de Mello e Castro, Castilho empenhouse numa fervorosa defesa da autonomia da Capitania, que necessitava de "huma independência absoluta de Pernambuco".124 Entretanto, seus argumentos e pressupostos eram completamente distintos daqueles utilizados pelo desaparecido Mello e Castro, a começar por sua defesa da nomeação de naturais para alguns postos na Capitania, haja vista que "As repetidas providências de Vossa Magestade a favor dos naturaes e moradores destas colônias provão o quanto importão que os officios de Justiça e Fazenda se provejão em pessoas estabelecidas nellas, não se exigindo para elles qualificaçõens, que só se podem adquerir na metrópole [...]". 125

Por sua vez, demonstrando seu próprio entendimento em noções de racionalidade administrativa e "bom governo", o governador da Paraiba advertia que o mau serviço de Sua Majestade poderia ser evitado se não se multiplicassem "desnecessariamente os officios e empregos, como quasi sempre acontece com novos Estabelecimentos, quando se repartem a muitos afilhados e protegidos [...], donde nasce que são mal serviços e dar-se entrada as venalidades e as peitas que a miséria acceita com pejo ao princípio e depois exige legitimando-se com a multiplicação e cotinuação dos crimes.".26

Neste sentido, Castilho denunciava que os prejuizos ao bom governo se multiplicavam na Paraiba em virtude do estado de subordinação. Os efeitos nocivos da anexação a Pernambuco eram sentidos nos "[...] conflitos de jurisdicção e mando, que [...] estorrão e talves damnão de todo o Real Serviço e o Bem do Público". Freire de Castilho alertava que a oposição e ciúme entre o governador-general e o capitão-mor da Paraiba "he tanto mais prejudicial quanto mais figurão os subalternos a respeito de quem manda sobre elles [...]".127 Doravante, se as cobranças das rendas reais amargavam perdas em virtude dos desvios do Erário e dos percalços com a dupla tributação, as despesas da Paraiba também pelejavam com a subordinação à Junta da Fazenda de Pernambuco, donde provinham todas as ordens, até em matérias elementares, o que causava dependência e morosidade ao governo das finanças da Capitania. ${ }^{128}$

Como se vê, o capitão-mor da Paraiba conhecia bem a situação econômica, jurisdicional e, sobretudo, política da Capitania, tendo ciência dos embaraços provocados por um governo dependente de Pernambuco. Todavia, ao passo que reiterou a maioria das queixas veiculadas por seus antecessores, notavelmente pelo governador Jerónimo de Mello e Castro, Fernando Delgado Freire de Castilho utilizou argumentos muito distintos para defender a mesma desanexação. Suas noções de "bom governo" e "bem comum" muito divergiam das de governadores anteriores; por outro lado, o contexto também mudara bastante e a Coroa já não estava tão convencida de que a subordinação das capitanias do Norte a Pernambuco era a melhor solução para a racionalização da máquina administrativa. Os 
129

Ibidem, p. 214.

130

Ibidem.

131

Ibidem, p. 238.

132

Em meados do século XIX, o então governador da Província da Paraiba, engenheiro militar Henrique de B. Rohan, também tratou do tema: "Concluo destas observações, $1^{\circ}$ que a província tem recursos sufficientes, e até excedentes às suas necessidades; $2^{\circ}$ que a importação que até o presente se tem feito toda por cabotagem pode com toda segurança ser substituída pela directa, sem dependência de outra qualquer praça, visto como os nossos gêneros de exportação (assucar, algodão e couros) tem a melhor sahida em todos os mercados da Europa; $3^{\circ}$ finalmente, que só $a$ imprevidência dos nossos homens de negócio, ou o hábito que já tem contrahido de sujeitar todas as suas transações à praça de Pernambuco, tem concorrido para que elles não aproveitem, como devem os recursos da provincia em benefício desta, e em seu particular interesse, que por esta maneira se acharião [sic] em perfeito acordo" (ROHAN, Henrique de B. "Chorographia". Revista do Instituto Histórico e Geográfico Paraibano. Vol. 3. Parahyba: Imprensa Official, 1911, p. 253).

133

AHU - Paraiba, doc. 2257 (Monte-mor, 20/abr/1792). conflitos jurisdicionais entre os próprios oficiais metropolitanos enfim parecem ter preocupado os responsáveis pela alta política imperial, ao passo que a anexação de 1756 mostrou-se ineficiente no combate aos descaminhos dos direitos reais.

Seja como for, com a nova orientação aos rumos do Império português nesta última década de Setecentos, tendo como um de seus principais artífices o secretário $d$. Rodrigo de Sousa Coutinho, as justificativas de Fernando Delgado, embasadas em conhecimento empírico à moda da llustração portuguesa, parecem ter surtido melhores efeitos que os apelos de Jerónimo de Mello e Castro. A nosso ver, Castilho era o reflexo de um mundo um tanto distinto daquele no qual vivera Jerónimo José. Em 17 de janeiro de 1799, uma carta régia livrou a Capitania da Paraiba da subordinação em que se achava da de Pernambuco, alegando, dentre outras causas, o aumento populacional como fator primordial para a medida. A decisão de d. Maria I era estendida também ao governo do Ceará, feito independente pela primeira vez. 0 Rio Grande teve que esperar até 1817. Além dessas providências, a carta de Sua Majestade também ordenava a liberação completa do comércio nas capitanias do Norte, tanto diretamente com o reino (preferivel, mas não mais imposto) quanto intracolonial. ${ }^{129}$

Contudo, mesmo após a desanexação, é importante frisar que setores primordiais do governo econômico da Capitania da Paraiba continuaram em estreita relação com a vizinha Pernambuco, pois, apesar da provisão régia de 24 de janeiro de 1799 , $^{130}$ mandando organizar uma Junta da Fazenda na Paraiba, apenas em 1809 tal órgão foi efetivamente criado, passando as arrematações dos contratos a serem feitas na cidade da Paraiba. ${ }^{131}$ Doutra feita, os negócios, a política e as redes de sociabilidades continuaram a afrouxar as fronteiras entre as capitanias da Paraiba e Pernambuco, mesmo quando, avançados os Oitocentos, ambas tornaram-se províncias, ${ }^{132}$ denunciando cabalmente o equívoco dos governadores que defendiam 0 governo independente da Paraiba como melhor solução para tornar pujante o comércio pela praça da cidade da Paraíba. Como diziam acidamente os vereadores de Monte-mor, era este fundamento "frivolo por ser manifesto engano pensar que o vexame de fazer por força ir aquela cidade [da Paraíba] os effeitos há de tornala (sic) opulenta". ${ }^{133}$ 